\title{
Mechanisms of Inhibin Signal Transduction
}

\author{
Daniel J. Bernard, Stacey C. Chapman, and Teresa K. Woodruff \\ Department of Neurobiology and Physiology, Northwestern University, \\ 2153 N. Campus Drive, Evanston, Illinois 60208
}

\begin{abstract}
Inhibin was first identified as a gonadal hormone that potently inhibits pituitary follicle-stimulating hormone (FSH) synthesis and secretion. Although the notion of a nonsteroidal, gonadally derived inhibitory substance was realized in the early 1930s (McCullagh, 1932), identification of the hormone was not accomplished until more than $\mathbf{5 0}$ years later. At that time, inhibin was purified from bovine and porcine follicular fluid and was shown to be produced in two forms through dimeric assembly of an $\alpha$ subunit $(18 \mathrm{kDa}$ ) and one of two closely related $\beta$ subunits ( $\beta A$ and $\beta B$, approximately $14 \mathrm{kDa}$ ) (Ling et al., 1985; Miyamoto et al., 1985; Rivier et al., 1985; Robertson et al., 1985). Dimers of $\alpha$ and $\beta A$ and $\alpha$ and $\beta B$ subunits form inhibin $A$ and inhibin $B$, respectively. In the process of purifying inhibin, two groups also identified homo- and heterodimers of the inhibin $\beta$ subunits (Ling et al., 1986; Vale et al., 1986). These hormoncs, the activins, werc shown to potently stimulate FSH secretion from primary pituitary cultures and are now known to play important roles in growth and development (Woodruff, 1998; Pangas and Woodruff, 2000). Inhibins and activins are considered members of the transforming growth factor-beta (TGF- $\beta$ ) superfamily of growth and differentiation factors, based on a pattern of conserved cysteine residues in the $\alpha$ and $\beta$ subunits, similar to other ligands in the family.

Identification of the subunit proteins led to the cloning of their cDNAs and subsequently to their chromosomal mapping in several species (Mason et al., 1985,1986, Forage et al., 1986; Mayo et al., 1986; Esch et al., 1987; Woodruff et al., 1987; Barton et al., 1989; Hiendleder et al., 2000). Three additional activin-related $\beta$ subunits ( $\beta \mathrm{C}$ and $\beta \mathrm{E}$ in mammals and $\beta \mathrm{D}$ in Xenopus laevis) also have been identified but do not appear to play a role in FSH regulation (Hotten et al., 1995; Oda et al., 1995; Fang et al., 1996,1997; Loveland et al., 1996; Schmitt et al. 1996; O'Bryan et al., 2000; Lau et al., 2000). To date, only one $\alpha$ subunit has been reported. The inhibin subunits are expressed in various tissues (Meunier et al., 1988a,1988b) but the gonads are clearly the primary source of circulating inhibins (Woodruff et al., 1996). While inhibins act in a paracrine role in some tissues (Hsueh et al., 1987), their best-understood roles are as endocrine regulators of pituitary FSH. Activins also were purified from follicular fluid but because circulating activin levels generally are low, most actions of the hormones are likely to be paracrine in nature (Woodruff, 1998). Several reviews in the past decade have clearly and thoroughly addressed the characterization and regulation of the inhibins and activins and their roles in reproductive function (Vale et al., 1988; Ying, 1988; Woodruff and Mayo, 1990; Mayo, 1994; Woodruff and Mather, 1995).

In this chapter, we focus our attention on more-recent developments in inhibin research. First, we discuss differential regulation of inhibin isoforms. Specifically, we describe patterns of inhibin A and $B$ secretion in the context of the female reproductive cycle. Second, we review molecular mechanisms of inhibin subunit regulation. Third, while inhibins are best known for their role in
\end{abstract}


pituitary FSH regulation, other functions of the ligands are becoming better understood. We review the animal and human literature addressing the possible role of inhibins in gonadal cancers. While we know "what" inhibins do in various contexts, we have a very limited understanding of "how" the ligands have their effects on target cells. Recently, candidate inhibin receptor molecules have been identified (Draper et al., 1998; Hertan et al., 1999; Lewis et al., 2000; Chung et al., 2000). Next, we detail our current understanding of inhibin signal transduction. Finally, in light of the data reviewed here, we pose questions and outline future directions for inhibin research. While this review is concerned primarily with expression and function of inhibin, activin function and mechanisms of action are described where necessary to shed light on inhibin function. Several reviews of activin's role in reproductive and other processes can be found elsewhere (Woodruff, 1998; Pangas and Woodruff, 2000).

\section{Physiological Regulation of Inhibin Isoforms}

Inhibin A and B circulate in the female rat; however, the two hormones are differentially secreted across the 4-day estrous cycle (Woodruff et al., 1996). Inhibin B levels are elevated from the morning of metestrus and decline gradually through the morning of proestrus. At or shortly after the time of the primary gonadotropin surges on the afternoon of proestrus, inhibin B levels decline to their lowest levels until the morning of estrus, when they again begin to increase. Serum inhibin A levels, on the other hand, are low on metestrus morning and increase progressively through the afternoon of proestrus, where they peak at the time of the primary FSH and luteinizing hormone (LH) surges. Thereafter, serum inhibin A plummets to undetectable levels until the morning of estrus, when levels begin to increase, in response to FSH. These changes parallel changes in subunit mRNA levels in developing follicles (Meunier et al., 1988a; Woodruff et al., 1988; Woodruff and Mayo, 1990). In light of the fact that both forms of inhibin are elevated at the time of the primary FSH surge, the potent stimulatory effect of the hypothalamic gonadotropin-releasing hormone $(\mathrm{GnRH})$ surge is able to overcome the inhibitory effects of both inhibins. The subsequent declines in both inhibins then provide a permissive endocrine milieu for the secondary FSH surge on the morning of estrus. The elevated inhibin B levels early in the cycle likely function to keep FSH levels low following the secondary FSH surge. In fact, the very high negative correlation between inhibin B and FSH across the entirety of the cycle $(\mathrm{r}=-0.89)$ (Woodruff et al., 1996) suggests that, at least in rodents, inhibin B is the primary regulator of serum FSH. What, then, is the function of inhibin A across the rodent estrous cycle? It is likely that both inhibin A and B are required to suppress FSH secretion from the metestrus to proestrus transition, although the specific role of each ligand during this period has yet to be determined. Immunoneutralization studies with isoform-specific antibodies may help determine whether or not the two inhibins have different functions during the cycle.

Similar to the case in rodents, female primates show dissociated patterns of inhibin A and B secretion during their reproductive cycle (Groome et al., 
1994,1996; Welt et al., 1997b,1999; Sehested et al., 2000). Inhibin B levels are elevated during the early to midfollicular phase, then decline in the late follicular phase just prior to the primary gonadotropin surges. Inhibin $B$ then rises again around the time of the gonadotropin surges and declines to low levels during the luteal phase. Inhibin A levels are low during early to midfollicular phase but increase around the time of the preovulatory gonadotropin surges. Inhibin A levels remain elevated through the majority of the luteal phase, then decrease in synchrony with declining progesterone just prior to the luteal-follicular phase transition. Changes in serum inhibin A and B levels across the menstrual cycle in stump-tailed macaques are nearly identical to those in humans, except increases in inhibin A appear to occur only after the midcycle gonadotropin surges (Fraser et al., 1999).

The data in rats and humans indicate that changes in serum FSH are instrumental in driving these changes in inhibin production. In rats, unilateral ovariectomy produces a transient increase in serum FSH but not LH. After 24 hours, there is a compensatory increase in inhibin subunit mRNA levels in the follicles of the remaining ovary (D'Agostino et al., 1989). Serum FSH and inhibin B levels are highly correlated across the rat estrous cycle (Woodruff et al., 1996). While elevated inhibin B early in the cycle appears to keep FSH levels low, increased serum FSH during the secondary surge then seems to increase both inhibin A and $B$ production on estrus morning. Although increasing FSH levels stimulate inhibin expression during most phases of the cycle, primary gonadotropin surges drive the declines in inhibin A and B production (Woodruff et al., 1989). Blockade of the primary gonadotropin surges with a GnRH antagonist prevents decreases in inhibin subunit mRNA levels on the afternoon of proestrus. Exogenous FSH or LH replacement in antagonist-treated animals decreases ovarian inhibin expression, showing a direct role for gonadotropins in this process. Clearly, different mechanisms control FSH-regulated inhibin expression during the primary surges and at other times of the cycle (see below).

In primates (including humans), a strong correlation exists between inhibin $\mathrm{B}$ and FSH during the follicular phase and the preovulatory gonadotropin surges. In both cases, increases in FSH are followed within 1-2 days by increases in inhibin B (Sehested et al., 2000). The increasing inhibin B levels are almost invariably associated with declining FSH levels. Thus, it appears that increasing FSH levels stimulate inhibin B secretion, which then feeds back to the pituitary to downregulate FSH secretion. In humans, FSH administration during the early follicular phase results in a robust and dose-dependent response by both inhibin B and inhibin A, although inhibin B is more responsive to a lower dose of gonadotropin (Burger et al., 1998).

The relationship between inhibin B and FSH has been demonstrated most clearly in GnRH antagonist-treated stump-tailed macaques where exogenous FSH stimulates inhibin B, but not inhibin A, secretion (Fraser et al., 1999). In addition, 
exogenous inhibin A treatment during the early follicular phase fails to decrease serum FSH (Fraser and Tsonis, 1994); immunoneutralization with $\alpha$-subunit antisera during the midluteal phase (when inhibin $\mathrm{A}$ is elevated) does not increase serum FSH in this species (Fraser et al., 1992). These data suggest that inhibin A may neither regulate nor be regulated by FSH in stump-tailed macaques. Similarly, treatment of metestrous female rats with rh-inhibin A fails to inhibit FSH levels, while administration of an identical dose on proestrus results in a prompt (i.e., within 1 hour) and sustained suppression of serum FSH (Woodruff et al., 1993b). In contrast, when porcine follicular fluid is administered on metestrus, serum FSH levels can be suppressed, eliminating the mundane interpretation that FSH levels are already at their lowest levels (Grady et al., 1981). Instead, these data suggest that something else contained within porcine follicular fluid, perhaps inhibin B, is a more-potent regulator of FSH on metestrus than is inhibin A.

In contrast to the stump-tail macaque and rat, administration of rh-inhibin $A$ to rhesus monkeys during the early follicular as well as the midluteal phase suppresses FSH, but not LH, release (Stouffer et al., 1994; Molskness et al., 1996). Because inhibin B rather than inhibin A is the dominant ligand of the follicular phase, adminstration of any amount of the A-isoform can be called supraphysiological, raising the possibility that the response in the rhesus monkey was achieved because of dose. Is it possible that the pituitary integrates an inhibin $B$ signal differently than an inhibin A signal? Interestingly, both primate and rodent males produce inhibin B rather than inhibin A (de Kretser et al., 1989; LambertMesserlian et al., 1994; Illingworth et al., 1996; Woodruff et al., 1996; Plant et al., 1997). This isoform is thought to be the primary regulator of FSH (Illingworth et al., 1996; Ramaswamy et al., 2000). Until inhibin A and inhibin B can be administered to or specifically eliminated from rodent models, subhuman primates, and humans, the specific contribution of these ligands to control of the various phases of the reproductive cycle remains to be clarified.

In summary, inhibin A and B are differentially regulated across the female reproductive cycle in rodents and primates. In most cases, there is a negative correlation between FSH and inhibin levels, consistent with the feed-forward/feed-back relationship proposed for these hormones. In both rats and primates, this relationship appears to be stronger for inhibin B than for inhibin A, although this can be seen more clearly in primates, where there is a greater temporal dissociation between patterns of inhibin A and B secretion. Preferential isoform release may reflect differential regulation of $\beta$-subunit transcription or translation as well as regulation of dimer assembly and secretion. An emerging concept is that inhibin A and inhibin B may serve different biological functions, particularly with respect to FSH regulation. This might be accomplished by a number of different mechanisms, chief among them, the presence of specific inhibin A or inhibin B receptors in the pituitary. Next, we turn to a discussion of 
the possible role of differential inhibin subunit transcription, then to the issue of inhibin isoform-specific receptors.

\section{Molecular Regulation of Inhibin Subunits}

The mechanisms regulating differential inhibin $A$ and $B$ synthesis and secretion are not thoroughly understood. With the cloning of promoters for the different subunits in rats and humans (Feng et al., 1989; Pei et al., 1991; Dykema and Mayo, 1994; Tanimoto et al., 1996; Ardekani et al., 1998), we are beginning to understand transcriptional regulation of inhibin subunit genes. As discussed previously, gonadotropins are potent regulators of inhibin subunit gene expression. Both LH and FSH signal in target cells through G protein-coupled receptors and increase intracellular cAMP levels via activation of adenylyl cyclase. In fact, many of the effects of FSH and LH on inhibin subunit expression can be mimicked by treatment with 8-bromo-cAMP or forskolin (Mayo, 1994). Because all three subunits are stimulated by gonadotropins, how can differential patterns of inhibin $\mathrm{A}$ and $\mathrm{B}$ production be manifested? Transcriptional analyses have revealed some clues as to how the three subunits may be regulated differentially in the face of similar hormonal stimulation.

Currently, transcriptional regulation is best understood for the $\alpha$ subunit. A nonconsensus cAMP response element (CRE) in the rat inhibin $\alpha$ promoter appears to mediate gonadotropin (cAMP)-dependent gene expression (Pei et al., 1991). Gonadotropins stimulate cAMP response element binding protein (CREB) phosphorylation in rat primary granulosa cells (Mukherjee et al., 1996) and stimulate trancription via CREB-mediated interaction with the CRE in the $\alpha$ promoter (Pei et al., 1991). This provides an explanation for how the gonadotropins (specifically, FSH) stimulate inhibin $\alpha$ expression throughout the majority female reproductive cycle. However, after the primary gonadotropin surges on the afternoon of proestrus in rats, there is a rapid decline in $\alpha$-subunit production and in secretion of both inhibin A and B (Meunier et al., 1988a; Woodruff $e t$ al., 1988,1996). These declines are dependent on the gonadotropin surges (Woodruff et al., 1989). How can the same stimuli have seemingly opposite effects? In a series of elegant experiments, Mukherjee and colleagues (1998) provide at least one potential explanation. During the time of the primary surges, a robust and transient expression of the inducible cAMP early repressor (ICER) occurs in the ovary. ICER is the product of an intronic promoter in the CRE-modulatory protein (CREM) gene (Molina et al., 1993; Stehle et al., 1993). The protein contains the DNA binding and dimerization domains of the CREM protein but lacks the $\mathrm{N}$-terminal transactivation domain. Thus, ICER downregulates cAMP-dependent signaling, at least in part, by competitively binding CREs in target genes. ICER is not upregulated in proestrous animals treated with a GnRH antagonist, demon- 
strating the importance of gonadotropin surges in its expression. Thus, the decrease in inhibin $\alpha$ expression at this time may be explained by the transient expression of ICER in response to the LH (and FSH) surge. This proposed mechanism of action is supported by several observations. First, human chorionic gonadotropin (hCG, an LH-like molecule of placental origin), but not pregnant mare serum gonadotropin (PMSG, a source of FSH-like activity), stimulates ICER expression in cultured rat granulosa cells. Second, ICER binds the CRE in the $\alpha$-subunit promoter in a mouse granulosa cell line (GRMO2). Third, ICER attenuates basal and forskolin-stimulated $\alpha$-subunit promoter activity in GRMO2 cells.

Thus, at least for rats, the transient expression of ICER provides one mechanism whereby gonadotropins (e.g., FSH) can stimulate $\alpha$-subunit expression through the majority of the cycle but can inhibit expression just after the primary gonadotropin surges. While both LH and FSH stimulate cAMP production, only the very large cAMP signal generated specifically by LH may be sufficient to induce ICER expression (Mukherjee et al., 1998). Unlike the case in rats, however, in humans, $\alpha$-subunit and dimeric inhibin A are produced prior to and after the preovulatory gonadotropin surges. Does this suggest that ICER or some other repressor molecule is not similarly expressed in the human ovary following the LH surge? A close inspection of the data in humans indicates that inhibin A levels peak at the time of the LH surge, transiently decline, and then increase to elevated luteal levels (Welt et al., 1999; Sehested et al., 2000). Therefore, a transient repression may occur in humans, just as it does in rats. The primary difference, then, lies in the fact that human, but not rat, corpora lutea produce inhibin subunit mRNAs ( $\alpha$ and $\alpha \mathrm{A}$ ) and dimeric inhibin A (Davis et al., 1987; Woodruff et al., 1987; Meunier et al., 1988a; Roberts et al., 1993). The mechanisms controlling this interesting and important species difference are not well understood. However, there clearly is strong selective pressure in rodents to suppress luteal inhibin production. Continued inhibin production by ovulatory follicles after the LH surge would block the secondary FSH surge and recruitment of the next cohort of follicles (Schwartz and Channing, 1977).

While we are beginning to get a handle on inhibin $\alpha$ expression during the cycle (particularly in rats), mechanisms of $\beta$-subunit regulation are less clear. In rats, $\beta A$ and $\beta B$ subunit mRNA levels decrease around the time of the primary gonadotropin surges (Meunier et al., 1988a; Woodruff et al., 1988). The role of repressor molecules such as ICER in these declines has not been ascertained. In fact, while mRNA levels of both $\beta$ subunits are increased by FSH or forskolin (Turner et al., 1989; Dykema and Mayo, 1994; Woodruff et al., 1987), it is not clear that these increases reflect classical cAMP-dependent signal transduction. The rat $\beta A$ promoter is stimulated by forskolin and by the phorbol ester, 12-Otetradecanoylphorbol-13-acetate (TPA), in mouse GRMO2 cells (Ardekani et al., 
1998). Similar data have been reported for the human $\beta A$ promoter in HT1080 cells (Tanimoto et al., 1996). These data suggest that $\beta$ A, unlike $\alpha$, may be a target of both protein kinase $A(P K A)$ - and protein kinase $C$ (PKC)-mediated signal transduction. Interestingly, the rat $\beta A$ promoter contains a novel, nonconsensus $\mathrm{CRE}$ that is critical for both forskolin- and TPA-mediated transcription. However, signaling appears to be mediated via AP-1 (Jun-B and fos-B), and not by $\mathrm{CREB} /$ activating transcription factor (ATF), transcription factors. It is not clear how FSH, a stimulator of CAMP and the PKA pathway, stimulates the PKC pathway in granulosa cells, although FSH has been shown to stimulate jun-B in rat Sertoli cells (Hamil et al., 1994). Thus, one mechanism of differential $\alpha$ - and $\beta A$-subunit regulation may be accounted for by the use of PKA- vs. PKA/PKCdependent signaling (Tuuri et al., 1996; Ardekani et al., 1998). While this may provide a mechanism through which activin $A$ and inhibin $A$ may be differentially produced, it does not account for how inhibin $\Lambda$ and $B$ are differentially regulated.

Unlike $\alpha$ and $\beta A$, the $\beta B$ gene gives rise to two predominant transcripts in both ovaries and testes (see Table I) (Dykema and Mayo, 1994; Feng et al., 1995). These transcripts arise from use of two different promoters within the $5^{\prime}$ flanking region of the gene, which initiate transcription from sites spaced about $1 \mathrm{~kb}$ apart. Despite the fact that both transcripts are upregulated by FSH, forskolin, or 8bromo-cAMP in primary granulosa cells, neither promoter is stimulated by forskolin in these same cells (Dykema and Mayo, 1994). Similar results have been

\section{TABLE I}

Inhibit Subunit Characteristics

\begin{tabular}{llllll} 
Subunit & Chromosome & $\begin{array}{l}\text { Major mRNA } \\
\text { Transcript }(\mathrm{kb})\end{array}$ & $\begin{array}{l}\text { \# of } \\
\text { Exons }\end{array}$ & $\begin{array}{l}\text { Size } \\
\text { (Amino Acids) }\end{array}$ & $\begin{array}{l}\text { Mature Subunit } \\
\text { Size (a.a.) }\end{array}$ \\
\hline$\alpha$ & $2^{\mathrm{h}}, 1^{\mathrm{m}}, 2^{\mathrm{o}}$ & $1.5^{\mathrm{r}}$ & 2 & $366^{\mathrm{r}}$ & $133^{\mathrm{r}}$ \\
$\beta A$ & $7^{\mathrm{h}}, 13^{\mathrm{m}}, 4^{\mathrm{o}}$ & $6.8^{\mathrm{r}}$ & 3 & $424^{\mathrm{r}}$ & $116^{\mathrm{r}}$ \\
$\beta B$ & $2^{\mathrm{h}}, 1^{\mathrm{m}}, 2^{\mathrm{o}}$ & $4.3-4.4$ and $3.3^{\mathrm{r}}$ & 2 & $411^{\mathrm{r}}$ & $115^{\mathrm{r}}$ \\
\hline
\end{tabular}

The three subunit genes have been chromusonally mapped in humans (h), mice (m), and sheep (o). Note that in all three species, the $\alpha$ and $\beta B$ genes map to the same chromosome (Barton et al., 1989; Hiendleder et al., 2000). The predominant mRNA transcript sizes in the gonads are indicated for rats (r) (e.g., Woodruff et al., 1987; Feng et al., 1989; Dykema and Mayo, 1994). The mRNAs are assembled from two exons for $\alpha$ and $\beta B$ and from three exons for $\beta A$ (see Mayo, 1994, for review). All three subunits are produced as prepro-hormones. The inhibin ligands are produced from the heterodimeric assembly of the so-called mature $\alpha$ subunit with one of the two $\beta$ subunits, which are cleaved from the C-terminal portion of the prepro-hormones. The sizes of the full-length and mature subunit proteins (in amino acids) are shown for rats (r) (Esch et al., 1987; Woodruff et al., 1987). 
observed in MA-10 Leydig tumor cells treated with cAMP or TPA (Feng et al., 1995). In human granulosa-luteal cells, $\beta B$ mRNA levels are unaffected by 8bromo-cAMP or TPA (Tuuri et al., 1996). Examination of both promoters fails to reveal consensus or variant CREs, which may account for the failure of cAMP or forskolin to stimulate these promoter constructs. However, anecdotal (Dykema and Mayo, 1994) and published reports (Najmabadi et al., 1993) indicate that these or similar promoter constructs are cAMP reponsive in different cell lines. Clearly, more work needs to be done to determine the role of cAMP-dependent signal transduction in $\beta \mathrm{B}$-subunit transcription.

In rats, $\beta A$ and $\beta B$ mRNA and protein are expressed in the same follicles and are regulated similarly across the cycle, with few exceptions (Meunier et al., 1988a). Therefore, regardless of the mechanisms regulating basal or stimulated expression of the $\beta$-subunit genes, it seems clear that some other, nontranscriptional mechanism must underlie the differential pattern of inhibin $A$ and inhibin $B$ secretion. Translational processing may not be involved, as both $\beta A$ and $\beta B$ protein levels mirror their mRNA levels (Meunier et al., 1988a). Instead, regulation is likely post-translational, involving dimerization and secretion. Unfortunately, relatively nothing is known about the regulation of these processes for inhibin. In humans, $\beta A$ - and $\alpha$-, but not $\beta B$-, subunit mRNAs are detected in human corpora lutea (Roberts et al., 1993). Therefore, unlike the case in rats, a transcriptional mechanism may participate in the differential release of inhibin A and B (particularly during the luteal phase) across the cycle.

In summary, all three subunits appear to be regulated by FSH in vivo and in vitro. Because the FSH receptor stimulates cAMP production following ligand binding, it appears that inhibin subunit transcription may be regulated by PKAdependent signaling. Promoter-reporter studies in primary granulosa cell culture indicate that both inhibin $\alpha$ and $\beta$ subunits are cAMP inducible. However, while the $\alpha$ subunit appears to be stimulated through conventional, PKA-mediated mechanisms, both PKA- and PKC-mediated pathways promote $\beta A$ transcription via AP-1 transcription factors that bind to a novel CRE. The role of cAMP in regulating the $\beta B$-subunit gene in rat granulosa cells is ambiguous. However, this pathway may be involved in $\beta B$ transcription in testicular Sertoli cells as well as in the ovary in vivo. The downregulation of inhibin production following gonadotropin surges in rats (and perhaps in humans) may be mediated by an LH-induced increase in ICER-mediated repression of cAMP-dependent gene expression. While this mechanism may account for the decline in all inhibin production at this time, the mechanisms through which inhibin A and B are differentially regulated throughout the cycle continue to be the subject of active investigation. 


\section{Inhibin and Cancer}

In addition to their roles in normal reproductive function, inhibins (and activins) have been implicated in pathologies of the reproductive system, including gonadal oncogenesis. This association is demonstrated most clearly in $\alpha$ subunit knockout mice. Both male and female mice homozygous for the null allele develop sex-cord gonadal tumors with 100 percent penetrance as early as 4 weeks of age (Matzuk et al., 1992). Castrated inhibin a knockout mice eventually develop adrenal tumors, indicating that inhibin acts as a tumor suppressor in multiple tissues (Matzuk et al., 1994). Importantly, inhibin $\alpha$ knockout mice engineered to produce inhibin $A$ through a mifeprisone-inducible system do not develop gonadal tumors, indicating that it is the absence of inhibin postnatally and not during development that causes tumor development (Pierson et al., 2000). In the absence of the $\alpha$ subunit, knockout mice produce very high levels of activin. However, these increased activin levels do not appear to cause the tumorigenic phenotype. Compound homozygous mutant mice deficient in both the $\alpha$ subunit and the ligand-binding activin receptor, actRII (Mathews and Vale, 1991), develop gonadal sex-cord tumors similar to those of the $\alpha$-subunit knockout animals (Coerver et al., 1996). However, it should be noted that activins may act via a second form of the receptor, actRIIB (Attisano et al., 1992), in these mice.

Another consequence of inhibin deficiency and activin overproduction is increased serum FSH levels (Matzuk et al., 1992). It is therefore possible that increased gonadotropin levels contribute to tumor development. Consistent with this argument, mice deficient in both the inhibin $\alpha$ subunit and GnRH (hpg) do not develop gonadal or adrenal tumors and live beyond 1 year of age (Kumar et al., 1996). While these data suggest that increased gonadotropin levels (FSH in particular) may drive the tumor development in $\alpha$-subunit knockouts, FSH alone does not appear to be responsible. Inhibin $\alpha$ and FSH- $\beta$ double-knockout mice develop gonadal tumors, although tumor onset is delayed, tumor phenotype is less extreme, and animals live longer than $\alpha$-subunit knockouts (Kumar et al., 1999). The role of LH in these animals is unclear, although it should be noted that transgenic mice overexpressing LH develop ovarian cysts and tumors (Risma et al., 1995).

There is also a relationship between ovarian cancer and inhibin in humans. Sex-cord stromal tumors are rare in humans, accounting for less than 10 percent of all cases of ovarian cancer. If inhibin acts as a tumor suppressor in humans as it does in mice, one would predict a decrease or absence of inhibin expression in these tumors. The opposite, in fact, appears to be the case. Several reports indicate inhibin $\alpha$ - and $\beta$-subunit expression in gonadal sex-cord tumors (Gurusinghe et al., 1995; Flemming et al., 1995,1996; Costa et al., 1997; Stewart et al., 1997; Yamashita et al., 1997; Zheng et al., 1997). In some cases, these tumors are 
associated with elevated circulating inhibin levels that are decreased following surgical resection (Lappohn et al., 1989; Silverman et al., 1994; Cooke et al., 1995; Yamashita et al., 1997). Serum FSH levels are inversely related to serum inhibin levels in some of these patients, indicating that the circulating inhibins are biologically active. Inhibin immunoreactivity also appears to be a good marker of testicular sex-cord stromal tumors (McCluggage et al., 1998). Thus, in apparent contrast to the case in mice, human sex-cord tumorigenesis is almost always associated with the presence, rather than the absence, of inhibin. Along these lines, it is interesting to note that, in human granulosa tumors, there is almost invariably no loss of heterozygosity ( $\mathrm{LOH}$ ) in the vicinity of the inhibin $\alpha$ gene on chromosome $2 \mathrm{q}$ (Watson et al., 1997), suggesting that inhibin is not aberrantly produced in these tumors. Interestingly, there is a $\mathrm{LOH}$ in this region in approximately 33 percent of the epithelial ovarian tumors examined. Thus, dysregulation of inhibin expression may be associated not with sex-cord stromal tumors but rather with epithelial ovarian cancer (EOC), the most-pervasive and deadly form of the disease.

In postmenopausal women, circulating inhibin levels are by-and-large undetectable (Burger et al., 1999). However, in many cases, postmenopausal women with EOC have elevated serum inhibin (Burger et al., 1996a; Blaakaer et al., 1993; Healy et al., 1993; Cooke et al., 1995; Frias et al., 1999). In one study (Blaakaer et al., 1993), increased survival was associated with elevated inhibin levels in postmenopausal women with malignant epithelial ovarian tumors, consistent with inhibin's proposed role as a tumor suppressor (Matzuk et al., 1992). However, a more-recent study indicates that elevated inhibin A levels may be a predictor of poor survival outcomes. In women with primary EOC, preoperative serum inhibin A levels above the median are associated with decreased disease-free survival and decreased overall survival in the 5 years after surgery (Frias et al., 1999). The apparent difference between these two studies may be attributed to the assays used to detect serum inhibins. The earlier study measured total serum inhibin (free $\alpha$ subunit as well as dimeric inhibin) (Blaakaer et al., 1993), while the later study used assays that measure both the free (pro- $\alpha \mathrm{C}$ ) and dimeric forms of inhibin (A and B) (Frias et al., 1999). There is some suggestion that free $\alpha$ subunit may be a better marker of EOC than dimeric inhibin A (Lambert-Messerlian et al., 1997; Burger et al., 1996b). The study by Frias and coworkers (1999) acknowledged both that overall inibin A levels were low in their patient population and that patients with pro- $\alpha \mathrm{C}$ levels above the median had a 2.4-fold increased chance of survival. Therefore, if the increased survival of patients with elevated inhibin levels in the Blaakaer study (1993) is related specifically to increased pro- $\alpha \mathrm{C}$, then the two studies may be consistent after all. In this case, elevated pro- $\alpha \mathrm{C}$ may provide a good survival marker, while increased inhibin A may be a marker of increased morbidity. 
What do these circulating hormone levels say about the underlying disease process? As discussed earlier, the lack of inhibin in $\alpha$-subunit knockout mice leads to sex-cord stromal tumorigenesis. One suggestion, therefore, is that, in the absence of the $\alpha$ subunit, unopposed activin dimer assembly occurs and activin may have a proliferative (oncogenic) effect on gonadal cells. Activin levels are, indeed, elevated in these animals (Matzuk et al., 1994). Activin production and secretion also are upregulated in EOC tumors, relative to normal ovarian epithelial cells (Welt et al., 1997a). However, deletion of actRII in $\alpha$-subunit knockouts does not alter the tumorigenic phenotype (Coerver et al., 1996). While activin stimulates proliferation in human ovarian cancer cell lines (that do not produce follistatin) (Di Simone et al., 1996), it does not consistently affect normal or EOC epithelia in primary culture (Welt et al., 1997a). Thus, the potential role of activin as a proliferative factor (and inhibin as an antiproliferative factor) in human EOC remains unclear.

In summary, inhibin acts as a sex-cord stromal tumor suppressor in mice but is upregulated in human sex-cord stromal tumors. While inhibin levels also are increased in human epithelial ovarian cancer, the source of inhibin and the role of the hormone in tumor development and progression are not thoroughly understood.

\section{Evidence for the Existence of an Inhibin Receptor}

Although we have learned a great deal about the regulation of inhibin production and secretion and about its endocrine and paracrine roles in reproductive physiology, we still know very little regarding how the hormone exerts its effects at a cellular and molecular level. This lack of knowledge stems mainly from the failure to identify and clone an inhibin receptor(s) and to characterize its underlying signal transduction pathway. This stands in sharp contrast to what has been learned about activin and its mechanisms of action during this same time period (Woodruff, 1998; Pangas and Woodruff, 2000). Given the failure to clone any inhibin receptors, one could speculate that none, in fact, exist. In this case, inhibin's actions may be mediated not by separate signaling mechanisms but rather via perturbation of activin signaling. There are at least two obvious ways in which inhibin could accomplish this task in the absence of its own receptor.

First, as described above, activins and inhibins share $\beta$ subunits. In many tissues, particularly the gonads, $\alpha$-subunit production is greater than that of the $\beta$ subunits. In these cases, inhibin production exceeds activin production. Therefore, where the $\alpha$ subunit is more abundant, activin production and, therefore, action is abrogated simply because less activin is available to act on target cells. Second, activin, like other members of the TGF- $\beta$ superfamily, binds a type II receptor (actRII or actRIIB), a receptor serine-threonine kinase (Mathews and Vale, 1991; 
Attisano et al., 1992; Mathews et al., 1992). Upon ligand binding, the type II receptor recruits and phosphorylates the activin type I receptor (Alk4 or actRIB), which is also a serine-threonine kinase (Attisano et al., 1993; Ebner et al., 1993; Tsuchida et al., 1993; Carcamo et al., 1994; ten Dijke et al., 1994). The type I receptor then phosphorylates intracellular signaling molecules in the Smad family (Smad2 or Smad3), which bind to another Smad protein (Smad4) before translocating to the nucleus to affect transcription of target genes. Inhibin binds to actRII via its $\beta$ subunit, albeit with lower affinity than does activin (Mathews and Vale, 1991; Xu et al., 1995; Martens et al., 1997). This binding does not stimulate recruitment or phosphorlyation of the type I receptor (LeBrun and Vale, 1997; Martens et al., 1997). Thus, in those situations where the concentration of inhibin exceeds that of activin, inhibin can competitively bind the type II receptor and block activin signaling. ${ }^{1}$

Do these two modes of antagonism describe the mechanisms for all inhibin action? If so, this would indicate that inhibin functions solely by regulating activin signaling. This may be the case but has it become increasingly clear that there are inhibin-specific binding proteins and mechanisms to modify or amplify an inhibin signal. Supporting this notion are the following experimental observations. First, high-affinity binding sites for inhibin have been identified in ovine pituitary cells in primary culture (Hertan et al., 1999). Second, several studies have demonstrated inhibin-specific binding sites in adult tissues. For example, iodinated inhibin A, but not iodinated activin A, binds to rat Leydig cells (Krummen et al., 1994). In addition, the adrenal, spleen, and bone marrow bind iodinated inhibin $A$ at much higher levels than they bind iodinated activin A (Woodruff et al., 1993a). Gonadal tumors derived from inhibin $\alpha$-subunit knockout mice bind iodinated inhibin $\mathrm{A}$ but bind iodinated activin $A$ at much lower levels. This inhibin binding is not displaced by excess unlabeled activin (Draper et al., 1998). These data indicate that the association between inhibin and target cells is mediated by an inhibinspecific receptor or binding protein and not solely via the activin type II receptors, or at least that an accessory protein forms a stable association between inhibin and actRII that is not easily disrupted by activin (Lewis et al., 2000).

Third, inhibin is not able to antagonize activin action in all contexts; in some situations, the two ligands appear to have similar effects. In KAR6 cells, erythroleukemia cells that inducibly overexpress actRII and Alk4, inhibin is unable to antagonizc activin-stimulated erythrodifferentiation, cell proliferation, activin receptor complex formation, and reporter gene activity, even at 128-fold higher concentrations of inhibin (LeBrun and Vale, 1997). Inhibin does not block

\footnotetext{
${ }^{\mathrm{I}}$ Functional antagonism also has been described between activin and the BMP OP-1 (BMP-7) during mesoderm formation, where OP-1 has been shown to bind to the activin type II receptor (Yamashita et al., 1995; Piek et al., 1999; Candia et al., 1997).
} 
activin-stimulated apoptosis in hepatocytes (Schwall et al., 1993) nor does it affect activin's suppression of corticotropin (ACTH) from AtT20 corticotrope cells (Bilezikjian et al., 1991). Both inhibin A and activin A stimulate primate oocyte maturation in vitro and cytochrome $\mathrm{P}_{50} \mathrm{O}_{17 \alpha}$ and $\mathrm{LH}$ receptor mRNA levels in porcine Leydig cells (Alak et al., 1996; Lejeune et al., 1997). Fourth, inhibin binding proteins have been identified in gonadal tumors from inhibin $\alpha$-subunit knockout mice, bovine pituitaries, and human erythroleukemia cells (K562) (LeBrun and Vale, 1997; Draper et al., 1998; Chong et al., 2000). Thus, several pieces of data converge to indicate the presence of an inhibin receptor or binding protein distinct from the activin type II receptors. As a result, both we and others embarked to identify this protein or proteins.

\section{Identification of Inhibin Binding Protein}

Initially, we employed an approach that had proven successful in the cloning of ligand binding receptors for TGF- $\beta$ ligands (Attisano et al., 1992). We used degenerate oligonucleotides directed against conserved portions of the activin type II (and later type I) receptors and attempted to amplify novel type II-like receptors from inhibin $\alpha$ knockout tumors and rat pituitaries by polymerase chain reaction (PCR). Given that inhibin and activin share common $\beta$ subunits and because inhibin binds activin type II receptors with low affinity (Mathews and Vale, 1991; $\mathrm{Xu}$ et al., 1995; Martens et al., 1997), it seemed reasonable to speculate that inhibin might signal through a type II-like receptor. However, this approach failed to produce any novel serine-threonine kinase receptors.

We next attempted to identify the inhibin receptor by expression cloning. We demonstrated that inhibin A, but not activin A, bound to gonadal tumors from inhibin $\alpha$ knockout mice (Draper et al., 1998). We therefore prepared a cDNA expression library from RNA extracted from these tumors, then screened transfected COS cells for their ability to bind iodinated inhibin A. An approach similar to this was used successfully to clone the first receptor in the TGF- $\beta$ superfamily, actRII (Matthews and Vale, 1991). Unfortunately, this approach also failed to generate any candidate inhibin binding molecules (see further discussion below).

With our third approach, we struck gold (Chong et al., 2000)! We used affinity chromatography to purify inhibin binding proteins. Operating under the assumption that the pituitary (the primary target of gonadally derived inhibin) would provide an enriched source of inhibin receptors, we purified membrane proteins from kilogram quantities of bovine pituitaries and ran them through a recombinant human ( $\mathrm{rh}$ ) inhibin $\mathrm{A}$ affinity column. The proteins retained within the column were then eluted and subjected to sodium dodecyl sulfate-polyacrylamide gel electrophoresis (SDS-PAGE) under reducing conditions. About 20 to 25 proteins were purified in this fashion; however, one protein with an apparent 
molecular mass of $142 \mathrm{kDa}$ was decreased significantly in abundance when the membrane proteins were pre-incubated with rh-inhibin A prior to column purification. The membrane proteins were purified to homogeneity using reverse-phase high-performance liquid chromatography (HPLC), subjected to SDS-PAGE, transferred to polyvinylidene difluoride (PDVF), and stained with Coomassie blue. The $142-\mathrm{kDa}$ protein was cut from the membrane and microsequenced. A 17-amino acid oligopeptide sequence was determined and used to search GenBank using the BLASTP algorithm. The sequence corresponded to two published human cDNAs in the database (AF034198 and Y10523) (Frattini et al., 1998; Mazzarella et al., 1998), mapping to a gene on human chromosome Xq25. The gene is comprised of 19 exons and spans approximately $20 \mathrm{~kb}$ of genomic sequence (Frattini et al., 1998). The two reported sequences are virtually identical; however, one appears to contain an additional exon (exon 3) encoding nine amino acids predicted to be part of the N-terminal signal peptide (Frattini et al., 1998). Both reports identified at least two transcripts in polyA+ RNA from different human tissues, suggesting that different forms of the receptor may be expressed. We have identified at least three transcripts in total RNA from rat pituitary and testes and are in the process of characterizing the different forms (Chong et al., 2000; unpublished results).

The full-length human cDNAs are predicted to encode a single transmembrane-spanning protein of approximately $147 \mathrm{kDa}$. The protein, called immunoglobulin domain-containing gene 1 (IGDC1) (Frattini et al., 1998) or immunoglobulin superfamily gene 1 (IGSF1) (Mazzarella et al., 1998), contains an N-terminal signal peptide followed by 12 Ig-like domains organized into motifs of five and seven Ig loops, separated by a short, hydrophobic linker region. The protein has a transmembrane domain following the 12th Ig loop and a short, serine/threonine rich cytoplasmic tail. Unlike the type I and II receptors in the TGF- $\beta$ family, this protein does not contain any apparent kinase domain. Cleavage of the signal peptide produces a protein with a predicted molecular mass of $142 \mathrm{kDa}$, which corresponds to the $142-\mathrm{kDa}$ protein purified in the affinity column. The oligopeptide sequence was used to generate polyclonal antisera. In western blot analyses of bovine pituitary membrane proteins, these antisera detect a single protein of $142 \mathrm{kDa}$. In the original purification of proteins from the affinity column, we erroneously identified the protein to have a molecular mass of $120 \mathrm{kDa}$ and referred to the protein as p120 (Chong et al., 2000). Subsequent measurements confirmed a molecular mass of approximately $142 \mathrm{kDa}$. We now refer to this protein as inhibin binding protein (InhBP). 


\section{Criteria for Inhibin Receptor Designation}

During our cloning effort, we established four criteria that we believe must be satisfied in order to call InhBP or any other candidate molecule an inhibin receptor (Woodruff, 1999). First, it must be expressed in known inhibin target tissues. In particular, it must be expressed in pituitary gonadotropes. Second, the receptor must bind inhibin with high affinity. Third, this binding must be of high specificity but not necessarily exclusivity. That is, the molecule should bind inhibin with higher affinity than other ligands in the TGF- $\beta$ superfamily, although some low-affinity association with other ligands is possible (as is the case for inhibin $A$ and bone morphogenic protein (BMP)-7 with actRII) (Matthews and Vale, 1991; Yamashita et al., 1995). Fourth, the molecule must provide a mechanism for functional antagonism of activin signaling.

Consistent with the first criterion, we initially identified InhBP in bovine pituitaries. However, this result did not demonstrate expression of the protein specifically within FSH-producing gonadotropes. We addressed this issue during more-extensive studies in rats. RNA blot analyses show a high level of InhBP expression in rat pituitary and a lower, but still detectable, level of expression in the testis (Chong et al., 2000). We since have observed high levels of InhBP expression in pituitaries of a variety of species, including mice, sheep, and cows. In situ hybridization analyses in rats indicate that InhBP mRNA is expressed exclusively within the anterior pituitary in a pattern similar to that of the FSH- $\beta$ subunit mRNA (unpublished observation). Immmunohistochemical studies using the polyclonal antisera described above have identified InhBP protein within the anterior pituitary, where it co-localizes with FSH protein. In addition, InhBP protein is abundantly expressed in testicular Leydig cells (Chong et al., 2000). Importantly, Leydig cells previously have been shown to be targets of inhibin, but not activin, binding (Krummen et al., 1994). Thus, InhBP satisifies the first criterion for designation as an inhibin receptor or binding protein.

To explore binding affinity and specificity of inhibin to InhBP, we have performed transient transfection of human InhBP and ligand binding studies in monkey kidney epithelial cells, CV-1. These cells, which do not endogenously express InhBP, do not bind iodinated inhibin A. However, transfection of fulllength InhBP is sufficient to confer binding to these cells. We currently are using this cell culture system to determine binding affinity and specificity. Preliminary observations indicate that inhibin $A$ binds these transfected cells with high affinity. In addition, while other TGF- $\beta$ ligands (e.g., activin A, TGF- $\beta 1$ ) appear to bind InhBP, they do so with lower affinity than inhibin $A$. We are currently confirming and extending these preliminary observations. Thus, while the data look promising, we cannot yet confirm that InhBP satisfies that second and third criteria stipulated previously. The fourth criterion holds that the candidate inhibin receptor must provide a mechanism for antagonism of activin signaling in target 
cells. We have dedicated much effort to the elucidation of InhBP's role in inhibinmediated antagonism of activin action; these data are reviewed below.

As we were characterizing InhBP as a candidate inhibin receptor, the TGF- $\beta$ type III receptor, betaglycan, was identified as a potential inhibin receptor (Lewis et al., 2000). This molecule appears to satisfy all of the criteria for designation as an inhibin receptor. First, betaglycan is expressed in inhibin target tissues, including testicular Leydig cells and pituitary gonadotropes (Lewis et al., 2000; MacConnell and Vale, 2000). Second, unlike InhBP, betaglycan alone does not bind inhibin A or at least does so with low affinity. However, in the presence of actRII, betaglycan confers high-affinity inhibin A binding to cells that do not normally bind inhibin. Third, this binding appears to be specific (although not exclusive). Excess activin $A$ is unable to disrupt the association among betaglycan, actRII, and inhibin A, although TGF- $\beta 1$ does disrupt formation of the complex. Fourth, betaglycan provides a mechanism for inhibin A antagonism of activin signaling via competition for actRII. That is, by binding betaglycan and actRII, inhibin blocks binding of activin to the type II receptor and subsequent recruitment of the signaling type I receptor. Because it requires actRII for high-affinity inhibin A binding and antagonism, betaglycan may best be thought of as a co-receptor (Lewis et al., 2000).

Next, we will review canonical signaling mechanisms within the TGF- $\beta$ superfamily, in order to provide the foundation for an understanding of how inhibin may antagonize activin signaling via InhBP.

\section{The Canonical TGF Holo-receptor Complex}

During the last 15 years, the signal transduction pathways initiated by TGF- $\beta$, activin, BMP, and Mullerian-inhibiting substance (MIS) have been well characterized. In comparison, understanding the mechanism of inhibin action has proceeded at a slower pace. The first of a large number of TGF- $\beta$ superfamily binding, signaling, and accessory receptors was described by Massague in 1985 (reviewed in Massague et al., 1987). Through affinity labeling using iodinated TGF- $\beta$, three distinct TGF- $\beta$ binding proteins were identified and designated type I, type II, and type III receptors, based on relative molecular weights (Massague, 1985; Cheifetz et al., 1986; Massague et al., 1987). Native gels suggested that these proteins existed as a heteromeric protein complex (Massague, 1985). The type II TGF- $\beta$ receptor resembled a newly identified type II activin receptor and shared a region of high homology within the intracellular serine-threonine kinase domain (Mathews and Vale, 1991; Lin and Wang, 1992). This activin receptor was identified in an AtT20 corticotroph library screen by ${ }^{125}$ I-activin A binding (Mathews and Vale, 1991). The resultant full-length positive clone was predicted to contain a single transmembrane domain, a cysteine-rich extracellular ligand 
binding domain, an intracellular serine-threonine kinase domain, and potential autophosphorylation sites. Identification of additional type II and type I activin and TGF- $\beta$ receptors was accomplished by cloning of proteins homologous within the predicted serine-threonine kinase domain (Attisano et al., 1992,1993; Mathews et al., 1992; Franzen et al., 1993; He et al., 1993; ten Dijke et al., 1993; Tsuchida et al., 1993). A growing number of type I and type II serine-threonine kinase receptors specific for other members of the TGF- $\beta$ superfamily, including the BMPs and MIS, have since been identified (Paralkar et al., 1991; di Clemente et al., 1994). All of these receptors are highly conserved within the serine-threonine kinase region and the functions of these receptors are highly conserved through evolution (Newfeld et al., 1999).

A series of TGF- $\beta$-resistant mink lung epithelial $(\mathrm{MvLu})$ cell lines deficient in either or both of the type I and II TGF- $\beta$ receptors provided initial insight into the role of these proteins in TGF- $\beta$ signal transduction (Boyd and Massague, 1989; Laiho et al., 1990,1991). Cells expressing only the type II receptor bound ligand but regained TGF- $\beta$ responsiveness upon reintroduction of the type I receptor protein, suggesting that the type I receptor was necessary for TGF- $\beta$ signal transduction but not for ligand binding (Laiho et al., 1991; Wrana et al., 1992). Introduction of a kinase-deficient type II receptor did not restore TGF- $\beta$ responsiveness or signal transduction. Thus, kinase activity as well as presence of the type I receptor was needed for TGF- $\beta$ signaling (Wrana et al., 1992). Accordingly, transphosphorylation of the TGF- $\beta$ and activin type I receptor by ligandbound type II receptor was found to be absolutely required for the assembly of the heteromeric receptor complex and signal transduction (Attisano et al., 1993,1996; Wrana et al., 1994; Tsuchida et al., 1995). Collectively, these data established the prevailing dual-receptor model of TGF- $\beta$ superfamily signal transduction involving heteromeric receptor complexes comprised of at least one type I receptor and one type II receptor.

Once activated, the heteromeric receptor complex phosphorylates and activates the downstream mediators of the signal, the Smad proteins (reviewed in Piek et al., 1999). Smad proteins are classified into three functional groups. Receptorspecific Smads are phosphorylated and activated by the heteromeric receptor complex: Smad 2 and Smad3 are phophorylated by TGF- $\beta$ and activin receptor complexes, while Smadl, Smad5, and Smad8 are activated by BMP type I receptors. Once activated, receptor-specific Smads associate with a common mediator Smad, Smad4, and together translocate to the nucleus, where they act as transcriptional co-factors (reviewed in Piek et al., 1999). The inhibitory Smad6 and Smad7 disrupt TGF- $\beta$ and activin signaling by preventing the phosphorylation, heteromerization, and translocation of the receptor-specific Smads (Imamura et al., 1997; Nakao et al., 1997; Hayashi et al., 1997). Smad6 interacts with the type I 
TGF- $\beta$, activin, and BMP receptors and interferes specifically with Smad2 and Smad1, but not Smad3, phosphorylation (Imamura et al., 1997; Ishisaki et al., 1999). Smad7 associates with TGF- $\beta$ and activin type I receptors and is capable of blocking Smad1, Smad2, and Smad3 phosphorylation (Nakao et al., 1997; Hayashi et al., 1997; Ishisaki et al., 1999; Kitamura et al., 2000). In Xenopus, Smad6 competes with Smad4 for binding to Smad1, thus blocking BMP signaling by preventing Smad1/Smad4 heteromerization and translocation to the nucleus (Hata et al., 1998).

The sharing of receptors by ligands and the formation of nontraditional heteromeric protein complexes add another dimension to the dual-receptor TGF- $\beta$ superfamily signaling model. For example, activin signals are transduced through the traditional type I/type II activin receptor complex and carried intracellularly by Smad2, Smad3, and Smad4. However, OP-1 (BMP-7) is also able to bind the type II activin receptor, which then forms a complex with the BMP type I receptor and transduces signals via Smad5 (Yamashita et al., 1995; Piek et al., 1999). Likewise, the ligand binding type II receptor for MIS (AMHRII) was found to form a functional receptor complex with the BMP type IB receptor and activate Smadl (di Clemente et al., 1994; Gouedard et al., 2000). Finally, the type I receptor TSR-1 (Tsk 7L) is capable of transducing either activin or TGF- $\beta$ signals in the presence of the appropriate type II receptor (Ebner et al., 1993). Thus, signaling specificity among TGF- $\beta$ superfamily members is determined in part by the complement of receptors and Smad proteins expressed in particular tissues.

\section{Modulation of TGF- $\beta$ Superfamily Signaling}

Modulation of TGF- $\beta$ superfamily signal transduction can occur through the action of the type III receptors, now referred to as the accessory signaling proteins. (Fig. 1). Cell surface accessory proteins are capable of binding ligand and interacting with the heteromeric receptor complex but have short intracellular domains with no intrinsic enzymatic activity (reviewed in Piek et al., 1999). Therefore, these accessory proteins modulate TGF- $\beta$ superfamily signaling by regulating delivery of ligand to the heteromeric signaling receptor complex or by modulating the assembly of the receptor complex. Because accessory proteins have restricted tissue expression patterns, it is hypothesized that responsiveness of a particular cell type to TGF- $\beta$ family members depends on the availability of not only the type $I$ and type II receptors but also on the availability of accessory signaling molecules.

The best-characterized accessory proteins are betaglycan and endoglin. Betaglycan, once called the TGF- $\beta$ type III receptor, is a membrane proteoglycan consisting of a core protein of approximately $100-120 \mathrm{kDa}$ with two regions of glycosylaminoglycan (GAG) attachment sites; a transmembrane domain; and a 


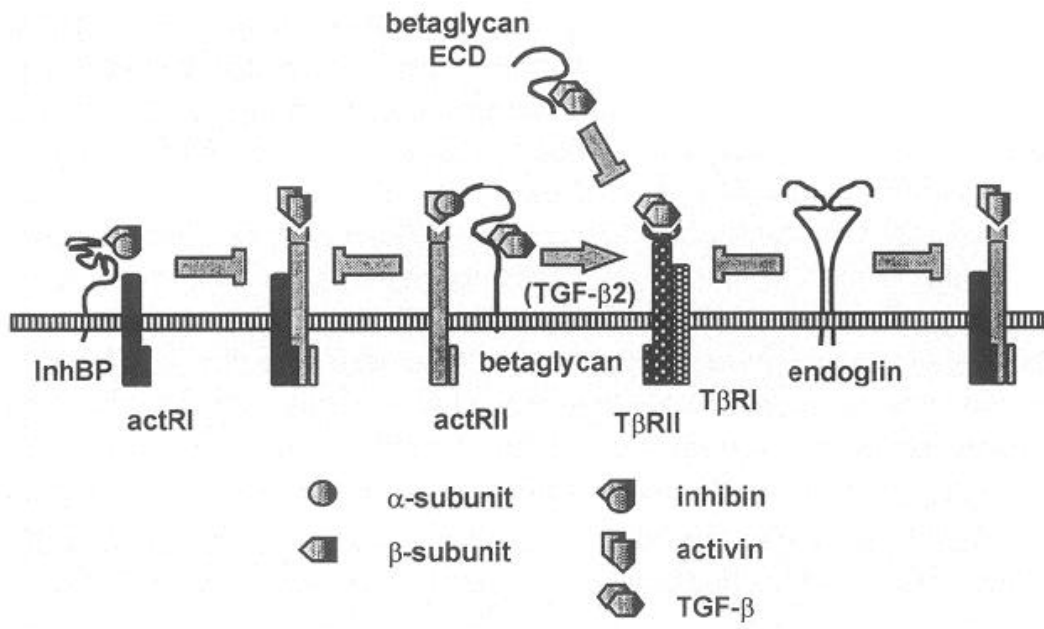

FIG. 1. Accessory proteins modify TGF- $\beta$ superfamily interactions with cell-surface receptors. The inhibin accessory protein, InhBP, can dissociate activin receptor complexes in the presence of inhibins (primarily inhibin B) and antagonize the action of that activin by rendering the receptor complex physically unable to associate. Other accessory proteins in the TGF- $\beta$ superfamily (e.g., endoglin, soluble betaglycan) act to disrupt TGF- $\beta$ signals by preventing stable receptor complex assembly. Accessory proteins also can facilitate signal transduction. For example, membrane-bound betaglycan facilitates TGF- $\beta 2$ access to TGF- $\beta$ receptors, enabling this ligand to act. Thus, an emerging theme for the mechanism of TGF- $\beta$ superfamily signal transduction is that accessory proteins are available to modify the net signal received by a cell for a given class of ligands. In addition, cells may use differential accessory protein expression to modify an existing signal. This idea is supported by the pattern of InhBP expression during the rat estrous cycle. Specifically, InhBP expression levels are highest during the follicular phase (when inhibin acts) and lowest at the time of the secondary FSH surge (when inhibin signals must be eliminated). Thus, the response of a cell to a given ligand may be modified by the presence of pre-existing or regulated receptor components at the cell surface.

short, serine-rich cytoplasmic tail (Cheifetz et al., 1998a; Lopez-Casillas et al., 1991,1994; Moren et al., 1992; Ponce-Castaneda et al., 1998). Betaglycan binds all three isoforms of TGF- $\beta$ and associates with ligand-bound type II receptor (Massague, 1985, Cheifetz et al., 1988a), increases the affinity of the type II receptor for TGF- $\beta$, and enhances cell responsiveness to TGF- $\beta 2$ (Lopez-Casillas et al., 1993). In fact, the affinity of the TGF- $\beta$ type II receptor is lower for TGF- $\beta 2$ than TGF- $\beta 1$ and -3 (Chiefetz, et al., 1990), yet cell types that express betaglycan respond to all three isoforms equally. Cells that do not express betaglycan respond poorly to TGF- $\beta 2$ (Ohta et al., 1987; Cheifetz et al., 1990). Thus, expression of this accessory protein can provide a degree of TGF- $\beta$ isoform signaling specific- 
ity. Betaglycan also exists in a soluble form that binds and sequesters TGF- $\beta$ and attenuates signaling (Andres et al., 1989, Lopez-Casillas et al., 1994). Therefore, betaglycan has been characterized as both a positive and negative regulator of TGF- $\beta$ signal transduction. As previously mentioned, betaglycan associates with actRII and, in the presence of inhibin, modifies the actions of activin. This function will be discussed in more detail later.

The betaglycan transmembrane and intracellular domains share 63 percent identity and 71 percent similarity with another signaling accessory protein, endoglin (Lopez-Casillas et al., 1991, Gougos and Letarte, 1990). Endoglin is a dimer consisting of a large, glycosylated, extracellular domain; one predicted transmembrane domain; and a serine-rich cytoplasmic tail. Endoglin was first identified as a vascular endothelial cell marker with an expression pattern similar to TGF- $\beta 1$ (Gougos and Letarte, 1988,1990). Indeed, endoglin was found to bind TGF- $\beta 1$ and TGF- $\beta 3$ but, unlike betaglycan, endoglin does not interact with TGF- $\beta 2$ (Cheifetz et al., 1992). Furthermore, endoglin assembles with the heteromeric receptor complexes of several members of the TGF- $\beta$ superfamily via the ligandbinding receptor component and acts as a negative regulator of signal transduction by these ligands (Barbara et al., 1999). Thus, endoglin appears to play a general role of a negative regulator of TGF- $\beta$ superfamily signal transduction.

\section{Variations on the TGF- $\beta$ Receptor Theme}

The inhibin $\alpha$ subunit sits on a distant branch of the TGF- $\beta$ superfamily tree (reviewed in Newfeld et al., 1999). However, because the inhibin heterodimer also includes an activin $\beta$ subunit, it was hypothesized (and hoped) that an inhibin receptor would resemble the traditional serine-threonine kinase receptors of activin and other TGF- $\beta$ superfamily proteins. Indeed, inhibin binds to the activin type II receptor, albeit at 10 -fold lower affinity than the activin dimer (Mathews and Vale, 1991, Mathews et al., 1992). However, initial attempts at cloning an inhibin receptor based on homology to the receptor serine-threonine kinase domain failed and it became clear that the mechanism of inhibin signal transduction would be unique.

Like inhibin, glial-derived neurotrophic growth factor (GDNF) is a distant member of the TGF- $\beta$ superfamily (reviewed in Newfeld et al., 1999). GDNF is involved in growth and differentiation of midbrain and peripheral neurons in vertebrates (Lin et al., 1993; Trupp et al., 1995). GNDF signals through a dualreceptor mechanism; however, the receptors are not serine-threonine kinases. GDNF binds to a GPI-anchored, cell-surface protein called GDNFR- $\alpha$, which has no intrinsic kinase activity (Jing et al., 1996; Treanor et al., 1996). Affinity-labeling experiments established that GDNFR- $\alpha$ binds GDNF and that this binding is 
abolished upon cleavage of the GPI anchor (Jing et al., 1996; Treanor et al., 1996). However, because GDNF is localized to the extracellular surface of the membrane and has no signaling capacity, it was hypothesized that another component was necessary to transduce a GDNF signal intracellularly. The proto-oncogene and receptor tyrosine kinase c-ret was identified as the second component of the GDNF signaling system, based on the overlapping patterns of GDNF and c-ret protein expression in the kidney and gut and on the similar phenotypes of mice deficient in either GDNF or c-ret (Schuchardt et al., 1994; Pichel et al., 1996; Sanchez et al., 1996; Moore et al., 1996). Once bound by GDNF, GDNFR- $\alpha$ associates with the Ret tyrosine kinase (Jing et al., 1996; Treanor et al., 1996). The ability of GDNF to promote axonal outgrowth in nephrogenic explants of $\mathrm{Ret}^{+/-}$but not $\mathrm{Ret}^{-1-}$ mice verified that Ret is necessary for GDNF signaling (Durbec et al., 1996). Thus, although the GDNF receptors do not utilize serinethreonine kinase receptors, the general dual-receptor mechanism of the superfamily is maintained. More intriguing is the fact that the GDNF signaling system incorporates elements of the two major growth factor families: 1) the dual-receptor mechanism of the TGF- $\beta$ superfamily and 2 ) the tyrosine kinases utilized by the large family of growth and differentiation factors, including epithelial growth factor (EGF) and insulin-like growth factor-1 (IGF-1) (reviewed in van der Geer et al., 1994).

GDF-9 is another distant member of the TGF- $\beta$ superfamily, although no receptor for this ligand has been identified. GDF-9 is expressed exclusively in the ovary and is absolutely required for preantral follicle devclopment (Dong et al., 1996; Hayashi et al., 1999). Treatment of cultured granulosa cells with recombinant GDF-9 stimulates the expression of several granulosa cell products, providing strong evidence for the existence of a GDF-9 receptor (Elvin et al., 1999). The C-terminal regions of GDF-9 and BMP-4 are highly homologous. However, unlike other TGF- $\beta$ superfamily proteins, GDF-9 lacks the conserved cysteine residues necessary for the formation of dimers (McPherron and Lee, 1993). Thus, although GDF-9 signals may be transduced through a traditional heteromeric receptor complex, it is also plausible that a unique receptor mediates GDF-9 effects on early folliculogenesis.

\section{Mechanism of Activin Antagonism}

With open minds, then, we have undertaken the task of elucidating either a novel and unique mechanism of inhibin signal transduction or one that partially resembles the dual-receptor model. Although we had a putative inhibin receptor in hand (i.e., InhBP), we had another obstacle to overcome: the lack of established inhibin responsive genes prevented a full understanding of inhibin signal transduction. For this reason, we and others (Lewis et al., 2000) have characterized the 
mechanism of inhibin action in terms of its ability to antagonize activin action. Of course, the best-known example of the opposing relationship between inhibin and activin is FSH production by the pituitary (Rivier et al., 1986). However, there is increasing evidence that inhibin also antagonizes the autocrine/paracrine actions of activin within the gonads. For instance, inhibin opposes inhibition of testosterone synthesis by activin in rat testicular and thecal cell cultures and inhibits activin-stimulated $3 \beta$-hydroxysteroid dehydrogenase (HSD) expression in porcine Leydig cells (Hsueh et al., 1987, Hillier et al., 1991, Lejeune et al., 1997, Lin et al., 1989). We are currently characterizing potential inhibin-responsive genes from each of these target tissues and anticipate that these will permit a more-detailed analysis of inhibin-specific signal transduction pathways. In the meantime, we have proceeded using the tools found on the activin toolbelt.

\section{Modulation of Activin Signaling by InhBP}

As described in an earlier section, InhBP has no intrinsic kinase domain. Based on this observation, and because inhibin is known to bind weakly to the activin type II receptor, we investigated assembly of InhBP with the activin receptors. Through immunoprecipitation/immunoblotting experiments, we demonstrated a strong InhBP interaction with the type IB activin receptor and little, if any, assembly of InhBP with the type II or type IIB activin receptors. This was somewhat unexpected, given that inhibin has been shown to bind the type II activin receptor and because inhibin binds betaglycan in the presence of the activin type II receptor (Mathews and Vale, 1991; Mathews et al., 1992; Lewis et al., 2000). InhBP also was able to assemble with the dual-specificity type I receptor TSR1 and the BMP type IB receptor (Alk6). It should be noted that InhBP shares with endoglin the ability to associate with several TGF- $\beta$ superfamily receptors. Thus, we predict that, as an accessory receptor, InhBP may have a similarly broad role in modulation of TGF- $\beta$ superfamily signaling.

InhBP-actRIB assembly was observed in vivo in a ligand-independent manner in sheep and human pituitary lysates. In vitro, InhBP-actRIB association was stabilized in the presence of activin $\mathrm{A}$. This interaction dropped to 60 percent of basal upon addition of inhibin B, but not inhibin A, to the system. ActRIB was shown to interact with both InhBP and actRIIB; however, it is not yet known whether InhBP exists as part of a heterotrimeric protein complex with both type $I$ and type II receptors. Nevertheless, treatment of cells with activin $A$ and inhibin $B$, but not activin $A$ and inhibin $A$, resulted in a dissociation of actRIB and InhBP as well as disassembly of the type IB/type IIB activin receptor complex. Finally, InhBP supported inhibin B-, but not inhibin A-, mediated antagonism of activin A-stimulated gene transcription. Functional antagonism of activin-stimulated gene expression was observed when cells were treated with activin A and either form 
of inhibin. However, cells transfected with InhBP and treated with inhibin B resulted in greater than 90 percent antagonism of activin-stimulated p3TP-luc expression. Importantly and necessarily, inhibin A or B alone or in the presence of InhBP was unable to antagonize TGF- $\beta$-stimulated gene expression.

Our working model describes an inhibin B-InhBP-mediated dissociation of the heteromeric activin receptor complex, which leads to abrogation of activin signal transduction and activin-stimulated gene expression. We propose that the presence of InhBP within the activin receptor complex renders it sensitive to inhibin $B$, such that low levels of inhibin B are capable of disrupting activin signaling. Cells in which InhBP is not expressed contain activin receptor complexes that are not as sensitive to inhibin treatment. In these cases, only a large excess of inhibin would be able to antagonize activin action.

The mechanism of inhibin B-InhBP-mediated dissociation of the heteromeric signaling complex is unknown. It is possible that InhBP may recruit endocytic machinery to the cell surface or that InhBP initiates receptor internalization by moving or tagging the activin receptor complex. Studies are currently underway to determine whether InhBP and inhibin B stimulate the ubiquitinization of the activin receptors. We are hesitant to rule out other means of antagonism of activin action by inhibin B and InhBP. For instance, inhibin and InhBP may initiate intracellular antagonism of activin signal transduction by activating the inhibitory Smad proteins (i.e., Smads 6 and 7) or through cross-talk with other pathways (e.g., the MAPK system), which has been shown to negatively regulate TGF- $\beta$ stimulated Smad activity (Kretzschmar et al., 1999).

The characterization of InhBP as a transducer of an independent inhibin signal has yet to be carried out, primarily due to the lack of available inhibinstimulated genes. It is possible that InhBP is a dual-function receptor involved in both inhibin signaling and inhibin-mediated activin antagonism. Indeed, several immunoglobulin domain-containing proteins are receptors. For example, the growth factor receptors of EGF and platelet-derived growth factor (PDGF) exhibit intrinsic tyrosine kinase activity and activate the MAPK signal transduction pathway (reviewed in Buck, 1992), while the cell adhesion molecule, N-CAM, is believed to transduce signals by initiating protein phosphorylation and activation of intracellular second messengers (reviewed in Goridis and Brunet, 1992). More interestingly, the receptors for two cysteine knot-containing proteins, vascular endothelial growth factor (VEGF) and nerve growth factor (NGF), contain immunoglobulin-like domains. Furthermore, the co-crystal structure of BMP-2 and the ectodomain of its ligand binding receptor, BMPRI, recently was solved and reveals a surprising and striking similarity to the co-crystal structures of VEGF and NGF with their respective receptors, Flt-1 and TrkA (Kirsch et al., 2000; Wiesmann and de Vos, 2000). These findings provide a compelling link between 
immunoglobulin domain-containing receptors and their corresponding cysteine knot-containing ligands.

Nevertheless, it is also possible that the positive and antagonistic actions of inhibin are supported by mutually exclusive receptors. The identification of inhibin-regulated genes is necessary to answer this question. Likewise, the discovery of the signaling molecules that lie downstream of InhBP is essential to understanding the mechanism(s) of inhibin signal transduction. Our finding that InhBP interacts with other TGF- $\beta$ receptors indicates that inhibin may signal through the Smad proteins.

\section{Future Directions}

Clearly, these are exciting times in inhibin research. The development of ligand-specific assays has revealed that inhibin A and B are differentially regulated across primate and rodent reproductive cycles, inhibin has been implicated in cancers of the reproductive system, and we are finally on the threshold of understanding how inhibin signals are conveyed to target cells.

\section{A. DIFFERENTIAL REGULATION OF INHIBIN ISOFORMS}

The data clearly indicate that inhibin A and B are differentially secreted across the female reproductive cycle. In addition, adult males appear to secrete inhibin B but not inhibin A (Woodruff et al., 1996). These observations beg the question, what is the functional significance of differential inhibin isoform secretion? Past research on inhibin action has relied heavily upon recombinant inhibin A, while little work on inhibin B has been reported. Therefore, we do not currently know the different roles or biological activities of the two ligands. There is certainly precedent for the belief that the two hormones will function differently. For example, we have shown that inhibin B, but not inhibin A, may use InhBP to antagonize activin actions. Inhibin $\mathrm{B}$ is more effective than inhibin $\mathrm{A}$ in blocking TGF- $\beta 1$ binding to $\mathrm{GH}_{3}$ rat pituitary cells (Cheifetz et al., 1988b). In addition, the different isoforms of activin (which share $\beta$ subunits with inhibin) have some redundant functions but clearly have different activities (Vassalli et al., 1994; Matzuk et al., 1995; Brown et al., 2000). The challenge for the immediate future is to develop model systems in which to assess the different functions of inhibin $\mathrm{A}$ and $\mathrm{B}$.

While the development of new assays to measure dimeric inhibins has revealed differential secretion of the two isoforms, we know little regarding how this is controlled. Although we are beginning to gain an appreciation for transcriptional regulation of the subunit genes, it is clear that transcriptional mechanisms alone cannot account for the different patterns of inhibin $A$ and $B$ release (at least not in rats). Perhaps there is regulation of dimer assembly but, at this point, we 
know little about how this is controlled. One report indicates that only when $\alpha$ subunit is expressed in excess of $\beta$ subunits is inhibin produced preferentially over activin (Mason, 1988). However, this does not address how different forms of inhibin may be differentially assembled. The signals controlling inhibin secretion may be the same for both ligands, with the differences in serum levels then reflecting different intracellular concentration of the two forms. Alternatively, different mechanisms may drive secretion of one form over the other. There is certainly precedent for this latter mechanism within the reproductive system. Both $\mathrm{LH}$ and FSH are produced and stored in the same gonadotrope cells in the anterior pituitary but the two hormones (which, like the inhibins, share a common $\alpha$ subunit) are differentially released. The frequency of $\mathrm{GnRH}$ pulses from the brain provides one mechanism governing this differential regulation of the two gonadotropins (Haisenleder et al., 1994). Future experiments need to address both the control of $\alpha \beta \mathrm{A}$ vs. $\alpha \beta \mathrm{B}$ assembly as well as the nature of the signals stimulating inhibin A vs. inhibin B release.

\section{B. INHIBIN AND CANCER}

Inhibin is normally expressed in the granulosa cells of the ovarian follicle and is abundantly expressed in granulosa cell tumors. It is not expressed in the surface epithelial layer of the ovary under normal conditions; however, it is detected in approximately 40 percent of pathology specimens from women with surface EOC. Therefore, production of inhibin by cancerous epithelial cells represents a failure of the molecular mechanisms governing cell-specific gene expression. An apparent conundrum exits between the relationship of inhibin and gonadal oncogenesis: a clear link has been demonstrated in animal models, yet the relationship in humans is less obvious. Does this contradict the proposed role of the ligands as tumor suppressors?

Inhibin production and secretion are often (although not always) associated with postmenopausal EOC. The role of the hormones, if any, in the disease process is not clear. Do aberrant inhibin production and signaling cause tumor development or growth, or do they merely reflect altered function of previously transformed, cancerous cells? At a minimum, it should be recognized that no mouse model has been generated that mimics human epithelial cell-derived ovarian cancer. The surface epithelia of the mouse and the human are similar in their role as the final boundary to the oocyte as it is expelled from the follicle into the oviduct. However, the epithelia of the rodent is protected from the peritoneal cavity by an extension of the oviduct, the bursal sac. One might conjecture that the rodent epithelia that must seal and re-seal six to eight times every 4 days is somehow resistant to the impacts of neoplasia. Alternatively, EOC is a product of an aging ovary and the mouse does not provide a suitable model for gerontological studies. An emerging line of thinking is that inhibin, similar to other 
cell-regulating molecules such as E2F1, may be functioning as both an oncogene and a tumor cell suppressor in certain tissues (Johnson, 2000). This dual action may depend on the ccll context (i.e., granulosa cell vs. surface epithelial cell) and may be responsive to the endocrine milieu at the time of altered expression (i.e., from birth or following follicular exhaustion). Clearly, new diagnostics and molecular tools are urgently needed to more fully understand EOC and then to intervene in disease. Inhibin may be one of many serum diagnostics that can be used but that may not be sufficiently predictive of disease at an earlier (moretreatable) stage. Alternatively, inhibin may participate in the onset or progression of disease; it is this latter point that bears examination.

\section{INHIBIN RECEPTORS}

While we have known for some time that inhibins can bind activin type II receptors, InhBP and betaglycan recently have been identified as putative inhibin receptors. While both molecules have provided novel insights into how inhibins abrogate activin signaling, many questions remain. First, can betaglycan and InhBP be described as receptors, despite the inability of these proteins to directly transduce a signal? To our way of thinking, the accessory proteins rightfully can be described as receptors. Like the cytokine Jak receptor system that depends upon extrinsic tyrosine kinases, the Stats, for signal transduction, the TGF- $\beta$ superfamily accessory proteins betaglycan and InhBP require association with the type II/type I complex in order to mediate a signal. Thus, the mechanism of signal transduction by the TGF- $\beta$ superfamily has expanded far beyond the traditional dual-receptor model to now include a role for accessory proteins in the modulation of signaling. Are InhBP and betaglycan the only inhibin receptors? If so, then all of inhibin action may be accounted for by perturbation or gating of activin signaling (Fig. 1). That is, in the models presented earlier, neither InhBP nor betaglycan interface with a signaling pathway. Rather, they describe mechanisms whereby inhibin can block access of activin to its signaling or ligand binding receptors. However, there are still some cases described in the literature where activin and inhibin appear to have similar effects (Lejeune $e t$ al., 1997). How can this occur if inhibin acts only by disrupting activin signaling? Perhaps InhBP and betaglycan interface with currrently unidentified signaling molecules or maybe other inhibin receptors exist. Future studies using protein-protein interaction methology (e.g., the yeast 2-hybrid system) will help identify potential signaling partners (and other interacting proteins) for these receptors.

Inhibin $A$ and $B$ are differentially regulated. Data suggest that the two ligands may serve different physiological roles. Are betaglycan and InhBP specific receptors for inhibin A and B, respectively? The data for InhBP indicate that the protein can bind both ligands but that it is superior in conveying inhibin B signals, in terms of antagonizing activin-stimulated gene transcription. Thus, InhBP may be 
an inhibin B receptor. Does betaglycan preferentially mediate inhibin A signals? There is certainly precedent for betaglycan mediating signals differently for closely related TGF- $\beta$ ligands (Mitchell et al., 1992; Lopez-Casillas et al., 1993). Given the established model system for betaglycan-mediated antagonism of activin signaling (Lewis et al., 2000), it should be straightforward to determine the relative efficacy of inhibin $A$ and $B$.

The cloning of these two receptors doubtlessly will clarify many existing questions within the field. This has already been demonstrated in several instances. For example, when working in K562 cells, LeBrun and Vale (1997) identified an inhibin-specific binding protein that forms a complex with inhibin $A$ and actRII. The data indicate that this binding protein is betaglycan (Lewis $e t$ al., 2000). In AtT20 cells, activin suppresses ACTH release, an effect that is not inhibited by inhibin. Interestingly, these cells do not express betaglycan endogenously (Wang et al., 1991). It will be important to demonstrate that transfection of betaglycan into these cells confers inhibin responsiveness and therefore abrogation of activin-induced suppression of ACTH release. Along these lines, inhibin attenuates activin-stimulated p3TP-luc activity in these cells but only after transfection of betaglycan. With relative ease, we should now be able to determine whether the inhibin binding proteins in $\alpha$-knockout tumors and ovine pituitaries (Draper et al., 1998; Hertan et al., 1999) correspond to InhBP or to betaglycan. Notably, we have identified high InhBP mRNA and protein levels in sheep pituitaries (unpublished observervation). If betaglycan, and not InhBP, confers inhibin binding to the tumors, this may account for our failure to identify an inhibin receptor by expression cloning. Betaglycan requires actRII for inhibin binding (Lewis et al., 2000; LeBrun and Vale, 1997). COS cells do not express actRII; thcrefore, even in transfected cells expressing betaglycan, we would have only seen negligible binding, if any at all.

Inhibin has relatively few defined target tissues, yet betaglycan (unlike InhBP) is ubiquitously expressed. Why, then, does inhibin not have morc wideranging effects? Because inhibin binding requires both betaglycan and actRII, inhibin action may be confined to those cells that express both receptors. Because InhBP does not appear to require other proteins for ligand binding, InhBP-mediated actions of inhibin may be defined by the narrow range of tissues in which the protein is expressed (most notably, the anterior pituitary).

In conclusion, we have learned much regarding inhibin regulation and function but many fascinating questions remain. Pursuit of the answers will keep inhibin researchers busy for some time to come.

\section{REFERENCES}

Alak, B.M., Smith, G.D., Woodruff, T.K., Stouffer, R.L., and Wolf, D.P. (1996). Fertil. Steril. 66, 646-653. 
Andres, J.L., Stanley, K., Cheifetz, S., and Massague, J. (1989). J. Cell Biol. 109, 3137-3145.

Ardekani, A.M., Romanelli, J.C., and Mayo, K.E. (1998). Endocrinology 139, 3271-3279.

Attisano, L., Wrana, J.L., Cheifetz, S., and Massague, J. (1992). Cell 68, 97-108.

Attisano, L., Carcamo, J., Ventura, F., Weis, F.M., Massague, J., and Wrana, J.L. (1993). Cell 75, $671-680$.

Attisano, L., Wrana, J.L., Montalvo, E., and Massague, J. (1996). Mol. Cell. Biol. 16, 1066-1073.

Barbara, N.P., Wranla, J.L., and Letarte, M. (1999). J. Biol. Chem. 274, 584-594.

Barton, D.E., Yang-Feng, T.L., Mason, A.J., Seeburg, P.H., and Francke, U. (1989). Genomics 5, 91-99.

Bilezikjian, L.M., Blount, A.L., Campen, C.A., Gonzalez-Manchon, C., and Vale, W. (1991). Mol. Endocrinol. 5, 1389-1395.

Blaakaer, J., Micic, S., Morris, I.D., Hording, U., Bennett, P., Toftager-Larsen, K., Djursing, H., and Bock, J.E. (1993). Eur. J. Obstet. Gynecol. Reprod. Biol. 52, 105-110.

Boyd, F.T., and Massague, J. (1989). J. Biol. Chem. 264, 2272-2278.

Brown, C.W., Houston-Hawkins, D.E., Woodruff, T.K., and Matzuk, M.M. (2000). Nature Genet. 25, 453-457.

Buck, C.A. (1992). Semin. Cell Biol. 3, 179-188.

Burger, H.G., Robertson, D.M., Cahir, N., Mamers, P., Healy, D.L., Jobling, T., and Groome, N. (1996a). Clin. Endocrinol. (Oxf.) 44, 413-418.

Burger, H., Hee, J., Bangah, M., Prince, M., McCloud, P., Ohara, A., Iwai, T., and Mori, T. (1996b). Clin. Endocrinol. (Oxf.) 45, 431-434.

Burger, H.G., Groome, N.P., and Robertson, D.M. (1998). J. Clin. Endocrinol. Metab. 83, 4167-4169.

Burger, H.G., Dudley, E.C., Hopper, J.L., Groome, N., Guthrie, J.R., Green, A., and Dennerstein, L. (1999). J. Clin. Endocrinol. Metab. 84, 4025-4030.

Candia, A.F., Watabe, T., Hawley, S.H., Onichtchouk, D., Zhang, Y., Derynck, R., Niehrs, C., and Cho, K.W. (1997). Development 124, 4467-4480.

Carcamo, J., Weis, F.M., Ventura, F., Wieser, R., Wrana, J.L., Attisano, L., and Massague, J. (1994). Mol. Cell. Biol. 14, 3810-3821.

Cheifetz, S., Like, B., and Massague, J. (1986). J. Biol. Chem. 261, 9972-9978.

Cheifetz, S., Andres, J.L., and Massague, J. (1988a). J. Biol. Chem. 263, 16984-16991.

Cheifetz, S., Ling, N., Guillemin, R., and Massague, J. (1988b). J. Biol. Chem. 263, 17225-17228.

Cheifetz, S., Hernandez, H., Laiho, M., ten Dijke, P., Iwata, K.K., and Massague, J. (1990). J. Biol. Chem. 265, 20533-20538.

Cheifetz, S., Bellon, T., Cales, C., Vera, S., Bernabeu, C., Massague, J., and Letarte, M. (1992). J. Biol. Chem. 267, 19027-19030.

Chong, H., Pangas, S.A., Bernard, D.J., Wang, E., Gitch, J., Chen, W., Draper, L.B., Cox, E.T., and Woodruff, T.K. (2000). Endocrinology 141, 2600-2607.

Coerver, K.A., Woodruff, T.K., Finegold, M.J., Mather, J., Bradley, A., and Matzuk, M.M. (1996). Mol. Endocrinol. 10, 534-543.

Cooke, I., O'Brien, M., Charnock, F.M., Groome, N., and Ganesan, T.S. (1995). Br. J. Cancer 71, 1046-1050.

Costa, M.J., Ames, P.F., Walls, J., and Roth, L.M. (1997). Hum. Pathol. 28, 1247-1254.

D'Agnstino, J., Woodruff, T.K., Mayn, K.E., and Schwartz, N.B (1989). Endocrinolngy 124, 310-317.

Davis, S.R., Krozowski, Z., McLachlan, R.I., and Burger, H.G. (1987). J. Endocrinol. 115, R21-R23.

de Kretser, D.M., McLachlan, R.I., Robertson, D.M., and Burger, H.G. (1989). J. Endocrinol. 120, 517-523.

di Clemente, N., Wilson, C., Faure, E., Boussin, L., Carmillo, P., Tizard, R., Picard, J.Y., Vigier, B., Josso, N., and Cate, R. (1994). Mol. Endocrinol. 8, 1006-1020.

Di Simone, N., Crowley, W.F., Jr., Wang, Q.F., Sluss, P.M., and Schneyer, A.L. (1996). Endocrinology 137, 486-494. 
Dong, J., Albertini, D.F., Nishimori, K., Kumar, T.R., Lu, N., and Matzuk, M.M. (1996). Nature 383, 531-535.

Draper, L.B., Matzuk, M.M., Roberts, V.J., Cox, E., Weiss, J., Mather, J.P., and Woodruff, T.K. (1998). J. Biol. Chem. 273, 398-403.

Durbec, P., Marcos-Gutierrez, C.V., Kilkenny, C., Grigoriou, M., Wartiowaara, K., Suvanto, P., Smith, D., Ponder, B., Costantini, F., Saarma, M., et al. (1996), Nature 381, 789-793.

Dykema, J.C., and Mayo, K.E. (1994). Endocrinology 135, 702-711.

Ebner, R., Chen, R.H., Lawler, S., Zioncheck, T., and Derynck, R. (1993). Science 262, 900-902.

Elvin, J.A., Clark, A.T., Wang, P., Wolfman, N.M., and Matzuk, M.M. (1999). Mol. Endocrinol. 13, 1035-1048.

Esch, F.S., Shimasaki, S., Cooksey, K., Mercado, M., Mason, A.J., Ying, S.Y., Ueno, N., and Ling, N. (1987). Mol. Endocrinol. 1, 388-396.

Fang, J., Yin, W., Smiley, E., Wang, S.Q., and Bonadio, J. (1996). Biochem. Biophys. Res. Commun. 228, 669-674.

Fang, J., Wang, S.Q., Smiley, E., and Bonadio, J. (1997). Biochem. Biophys. Res. Commun. 231, 655-661.

Feng, Z.M., Li, Y.P., and Chen, C.L. (1989). Mol. Endocrinol. 3, 1914-1925.

Feng, Z.M., Wu, A.Z., and Chen, C.L. (1995). Endocrinology 136, 947-955.

Flemming, P., Wellmann, A., Maschek, H., Lang, H., and Georgii, A. (1995). Am. J. Surg. Pathol. 19, 927-933.

Flemming, P., Grothe, W., Maschek, H., Petry, K.U., Wellmann, A., and Georgii, A. (1996). Histopathology 29, 465-468.

Forage, R.G., Ring, J.M., Brown, R.W., McInemey, B.V., Cobon, G.S., Gregson, R.P., Robertson, D.M., Morgan, F.J., Hearn, M.T., Findlay, J.K., et al. (1986). Proc. Natl. Acad. Sci. U.S.A. 83, 3091-3095.

Franzen, P., ten Dijke, P., Ichijo, H., Yamashita, H., Schulz, P., Heldin, C.H., and Miyazono, K. (1993). Cell 75, 681-692.

Fraser, H.M., and Tsonis, C.G. (1994). J. Endocrinol. 142, 181-186.

Fraser, H.M., Smith, K.B., Lunn, S.F., Cowen, G.M., Morris, K., and McNeilly, A.S. (1992). J. Endocrinol. 133, 341-347.

Fraser, H.M., Groome, N.P., and McNeilly, A.S. (1999). J. Clin. Endocrinol. Metab. 84, 1365-1369.

Frattini, A., Faranda, S., Redolfi, E., Allavena, P., and Vezzoni, P. (1998). Gene 214, 1-6.

Frias, A.E., Jr., Li, H., Keeney, G.L., Podratz, K.C., and Woodruff, T.K. (1999). Cancer 85, 465-471

Goridis, C., and Brunet, J.F. (1992). Semin. Cell. Biol. 3, 189-197.

Gouedard, L., Chen, Y.G., Thevenet, L., Racine, C., Borie, S., Lamarre, I., Josso, N., Massague, J., and di Clemente, N. (2000). J. Biol. Chem. 275, 27973-27978.

Gougos, A., and Letarte, M. (1988). J. Immunol. 141, 1934-1940.

Gougos, A., and Letarte, M. (1990). J. Biol. Chem. 265, 8361-8364.

Grady, R.R., Savoy-Moore, R.T., and Schwartz, N.B. (1981). In "Bioregulators of Reproduction" (G. Jagiello and H.J. Vogel, eds.), pp. 359-369. Academic Press, New York.

Groome, N.P., Illingworth, P.J., O'Brien, M., Cooke, I., Ganesan, T.S., Baird, D.T., and McNeilly, A.S. (1994). Clin. Endocrinol. (Oxf.) 40, 717-723.

Groome, N.P., Illingworth, P.J., O'Brien, M., Pai, R., Rodger, F.E., Mather, J.P., and McNeilly, A.S. (1996). J. Clin. Endocrinol. Metab. 81, 1401-1405.

Gurusinghe, C.I., Healy, D.L., Jnhling, T., Mamers, P., and Burger, H.G. (1995). Gynecol. Oncol. 57, 27-32.

Haisenleder, D.J., Dalkin, A.C., and Marshall, J.C. (1994). In "The Physiology of Reproduction" (E. Knobil and J.D. Neill, eds.), pp. 1793-1813. Raven Press, New York.

Hamil, K.G., Conti, M., Shimasaki, S., and Hall, S.H. (1994). Mol. Cell. Endocrinol. 99, 269-277.

Hata, A., Lagna, G., Massague, J., and Hemmati-Brivanlou, A. (1998). Genes Dev. 12, 186-197. 
Hayashi, H., Abdollah, S., Qiu, Y., Cai, J., Xu, Y.Y., Grinnell, B.W., Richardson, M.A., Topper, J.N., Gimbrone, M.A., Jr., Wrana, J.L., and Falb, D. (1997). Cell 89, 1165-1173.

Hayashi, M., McGee, E.A., Min, G., Klein, C., Rose, U.M., van Duin, M., and Hsueh, A.J. (1999). Endocrinology 140, 1236-1244.

He, W.W., Gustafson, M.L., Hirobe, S., and Donahoe, P.K. (1993). Dev, Dynam. 196, 133-142.

Healy, D.L., Burger, H.G., Mamers, P., Jobling, T., Bangah, M., Quinn, M., Grant, P., Day, A.J., Rome, R., and Campbell, J.J. (1993). N. Engl. J. Med. 329, 1539-1542.

Hertan, R., Farnworth, P.G., Fitzsimmons, K.L., and Robertson, D.M. (1999). Endocrinology 140, 6-12. Hiendleder, S., Dodds, K.G., and Wassmuth, R. (2000). J. Hered. 91, 343-345.

Hillier, S.G., Yong, E.L., Illingworth, P.J., Baird, D.T., Schwall, R.H., and Mason, A.J. (1991). Mol. Cell. Endocrinol. 75, R1-R6.

Hotten, G., Neidhardt, H., Schneider, C., and Pohl, J. (1995). Biochem. Biophys. Res. Commun. 206, 608-613.

Hsueh, A.J., Dahl, K.D., Vaughan, J., Tucker, E., Rivier, J., Bardin, C.W., and Valc, W. (1987). Proc. Natl. Acad. Sci. U.S.A. 84, 5082-5086.

Illingworth, P.J., Groome, N.P., Byrd, W., Rainey, W.E., McNeilly, A.S., Mather, J.P., and Bremner, W.J. (1996). J. Clin. Endocrinol. Metab. 81, 1321-1325.

Imamura, T., Takase, M., Nishihara, A., Oeda, E., Hanai, J., Kawabata, M., and Miyazono, K. (1997). Nature 389, 622-626.

Ishisaki, A., Yamato, K., Hashimoto, S., Nakao, A., Tamaki, K., Nonaka, K, ten Dijke, P., Sugino, H., and Nishihara, T. (1999). J. Biol. Chem. 274, 13637-13642.

Jing, S., Wen, D., Yu, Y., Holst, P.L., Luo, Y., Fang, M., Tamir, R., Antonio, L., Hu, Z., Cupples, R., Louis, J.C., Hu, S., Altrock, B.W., and Fox, G.M. (1996). Cell 85, $1113-1124$.

Johnson, D.G. (2000). Mol. Carcinog. 27, 151-157.

Kirsch, T., Sebald, W., and Dreyer, M.K. (2000). Nature Struct. Biol. 7, 492-496.

Kitamura, K., Aota, S., Sakamoto, R., Yoshikawa, S.I., and Okazaki, K. (2000). Blood 95, 3371-3379

Kretzschmar, M., Doody, J., Timokhina, I., and Massague, J. (1999). Genes Dev. 13, 804-816.

Krummen, L.A., Moore, A., Woodruff, T.K., Covello, R., Taylor, R., Working, P., and Mather, J.P. (1994). Biol, Reprod. 50, 734-744.

Kumar, T.R., Wang, Y., and Matzuk, M.M. (1996). Endocrinology 137, 4210-4216.

Kumar, T.R., Palapattu, G., Wang, P., Woodruff, T.K., Boime, I., Byrne, M.C., and Matzuk, M.M. (1999). Mol. Endocrinol. 13, 851-865.

Laiho, M., Weis, M.B., and Massague, J. (1990). J. Biol. Chem. 265, 18518-18524.

Laiho, M., Weis, F.M., Boyd, F.T., Ignotz, R.A., and Massague, J. (1991). J. Biol. Chem. 266, 9108-9112.

Lambert-Messerlian, G.M., Hall, J.E., Sluss, P.M., Taylor, A.E., Martin, K.A., Groome, N.P., Crowley, W.F., Jr., and Schneyer, A.L. (1994). J. Clin. Endocrinol. Metab. 79, 45-50.

Lambert-Messerlian, G.M., Steinhoff, M., Zheng, W., Canick, J.A., Gajewski, W.H., Seifer, D.B., and Schneyer, A.L. (1997). Gynecol. Oncol. 65, 512-516.

Lappohn, R.E., Burger, H.G., Bouma, J., Bangah, M., Krans, M., and de Bruijn, H.W. (1989). N. Engl. J. Med. 321, 790-793.

Lau, A.L., Kumar, T.R., Nishimori, K., Bonadio, J., and Matzuk, M.M. (2000). Mol. Cell. Biol. 20, 6127-6137.

Lebrun, J.J., and Vale, W.W. (1997). Mol. Cell. Biol. 17, 1682-1691.

Lejeune, H., Chuzel, F., Sanchez, P., Durand, P., Mather, J.P., and Saez, J.M. (1997). Endocrinology 138, 4783-4791.

Lewis, K.A., Gray, P.C., Blount, A.L., MacConell, L.A., Wiater, E., Bilezikjian, L.M., and Vale, W. (2000). Nature 404, 411-414.

Lin, H.Y., and Wang, X.F. (1992). Mol. Reprod. Dev. 32, 105-110.

Lin, L.F., Doherty, D.H., Lile, J.D., Bektesh, S., and Collins, F. (1993). Science 260, 1130-1132. 
Lin, T., Calkins, J.K., Morris, P.L., Vale, W., and Bardin, C.W. (1989). Endocrinology 125, 2134-2140.

Ling, N., Ying, S.Y., Ueno, N., Esch, F., Denoroy, L., and Guillemin, R. (1985). Proc. Natl. Acad. Sci. U.S.A. 82, 7217-7221.

Ling, N., Ying, S.Y., Ueno, N., Shimasaki, S., Esch, F., Hotta, M., and Guillemin, R. (1986). Nature 321, 779-782.

Lopez-Casillas, F., Cheifetz, S., Doody, J., Andres, J.L., Lane, W.S., and Massague, J. (1991). Cell 67, 785-795.

Lopez-Casillas, F., Wrana, J.L., and Massague, J. (1993). Cell 73, 1435-1444.

Lopez-Casillas, F., Payne, H.M., Andres, J.L., and Massague, J. (1994). J. Cell. Biol. 124, 557-568.

Loveland, K.L., McFarlane, J.R., and de Kretser, D.M. (1996). J. Mol. Endocrinol. 17, 61-65.

MacConell, L.A., and Vale, W. (2000). In "Program \& Abstracts of the 82nd Annual Meeting of The Endocrine Society," Toronto, Ontario, Canada, June 2000, abstract 552, p. 139.

Martens, J.W., de Winter, J.P., Timmerman, M.A., McLuskey, A., van Schaik, R.H., Themmen, A.P., and de Jong, F.H. (1997). Endocrinology 138, 2928-2936.

Mason, A.J. (1988). In "Nonsteroidal Gonadal Factors: Physiological Roles and Possibilities in Contraceptive Development" (G.D. Hodgen, Z. Rosenwaks, and J.M. Spieler, eds.), pp. 12-29. Jones Institute Press, Norfolk, Va.

Mason, A.J., Hayflick, J.S., Ling, N., Esch, F., Ueno, N., Ying, S.Y., Guillemin, R., Niall, H., and Seeburg, P.H. (1985). Nature 318, 659-663.

Mason, A.J., Niall, H.D., and Seeburg, P.H. (1986). Biochem. Biophys. Res. Commun. 135, 957-964.

Massague, J. (1985). J. Biol. Chem. 260, 7059-7066.

Massague, J., Cheifetz, S., Ignotz, R.A., and Boyd, F.T. (1987). J. Cell. Physiol. 5(suppl.), 43-47.

Mathews, L.S., and Vale, W.W. (1991). Cell 65, 973-982.

Mathews, I.S., Vale, W.W., and Kintner, C.R. (1992). Science 255, 1702-1705.

Matzuk, M.M., Finegold, M.J., Su, J.G., Hsueh, A.J., and Bradley, A. (1992). Nature 360, 313-319.

Matzuk, M.M., Finegold, M.J., Mather, J.P., Krummen, L., Lu, H., and Bradley, A. (1994). Proc. Natl. Acad. Sci. U.S.A. 91, 8817-8821.

Matzuk, M.M., Kumar, T.K., Vassalli, A., Bickenbach, J.K., Koop, D.R., Jaenisch, R., and Bradley, A (1995). Nature 374, 354-356.

Mayo, K.E. (1994). Trends Endocrinol. Metab. 5, 407-415.

Mayo, K.E., Cerelli, G.M., Spiess, J., Rivier, J., Rosenfeld, M.G., Evans, R.M., and Vale, W. (1986) Proc. Natl. Acad. Sci. U.S.A. 83, 5849-5853.

Mazzarella, R., Pengue, G., Jones, J., Jones, C., and Schlessinger, D. (1998). Genomics 48, 157-162.

McCluggage, W.G., Shanks, J.H., Whiteside, C., Maxwell, P., Banerjee, S.S., and Biggart, J.D. (1998). Am. J. Surg. Pathol. 22, 615-619.

McCullagh, E.P. (1932). Science 76, 19-20.

McPherron, A.C., and Lee, S.J. (1993). J. Biol. Chem. 268, 3444-3449.

Meunier, H., Cajander, S.B., Roberts, V.J., Rivier, C., Sawchenko, P.E., Hsueh, A.J., and Vale, W. (1988a). Mol. Endocrinol. 2, 1352-1363.

Meunier, H., Rivier, C., Evans, R.M., and Vale, W. (1988b). Proc. Natl. Acad. Sci. U.S.A. 85, 247-251

Mitchell, E.J., Fitz-Gibbon, L., and O'Connor-McCourt, M.D. (1992). J. Cell. Physiol. 150, 334-343.

Miyamoto, K., Hasegawa, Y., Fukuda, M., Nomura, M., Igarashi, M., Kangawa, K., and Matsuo, H. (1985). Biochem. Biophys. Res. Commun. 129, 396-403.

Molina, C.A., Foulkes, N.S., Lalli, E., and Sassone-Corsi, P. (1993). Cell 75, 875-886.

Molskness, T.A., Woodruff, T.K., Hess, D.L., Dahl, K.D., and Stouffer, R.L. (1996). J. Clin. Endocrinol. Metab. 81, 4002-4006.

Moore, M.W., Klein, R.D., Farinas, I., Sauer, H., Armanini, M., Phillips, H., Reichardt, L.F., Ryan, A.M., Carver-Moore, K., and Rosenthal, A. (1996). Nature 382, 76-79.

Moren, A., Ichijo, II, and Miyazono, K. (1992). Biochem. Biophys. Res. Commun. 189, 356-362.

Mukherjee, A., Park-Sarge, O.K., and Mayo, K.M. (1996). Endocrinology 137, 3234-3245. 
Mukherjee, A., Urban, J., Sassone-Corsi, P., and Mayo, K.E. (1998). Mol. Endocrinol. 12, 785-800.

Najmabadi, H., Rosenberg, L.A., Yuan, Q.X., Reyaz, G., and Bhasin, S. (1993). Mol. Endocrinol. 7, 561-569.

Nakao, A., Afrakhte, M., Moren, A., Nakayama, T., Christian, J.L., Heuchel, R., Itoh, S., Kawabata, M., Heldin, N.E., Heldin, C.H., and ten Dijke, P. (1997). Nature 389, 631-635.

Newfeld, S.J., Wisotzkey, R.G., and Kumar, S. (1999). Genetics 152, 783-795.

O'Bryan, M.K., Sebire, K.L., Gerdprasert, O., Hedger, M.P., Hearn, M.T., and de Kretser, D.M. (2000). J. Mol. Endocrinol. 24, 409-418.

Oda, S., Nishimatsu, S., Murakami, K., and Ueno, N. (1995), Biochem. Biophys. Res. Commun. 210, 581-588.

Ohta, M., Greenberger, J.S., Anklesaria, P., Bassols, A., and Massague, J. (1987). Nature 329, 539-541.

Pangas, S.A., and Woodruff, T.K. (2000). Trends Endocrinol. Metab. 11, 309-314.

Paralkar, V.M., Hammonds, R.G., and Redd, A.M. (1991). Proc. Natl Acad. Sci. U.S.A. 88, 3397-3401.

Pei, L., Dodson, R., Schoderbek, W.E., Maurcr, R.A., and Mayo, K.E. (1991). Mol. Endocrinol. 5, 521-534.

Pichel, J.G., Shen, L., Sheng, H.Z., Granholm, A.C., Drago, J., Grinberg, A., Lee, E.J., Huang, S.P., Saarma, M., Hoffer, B.J., Sariola, H., and Westphal, H. (1996). Nature 382, 73-76.

Piek, E., Heldin, C.H., and Ten Dijke, P. (1999). FASEB J. 13, 2105-2124.

Pierson, T.M., Wang, Y., DeMayo, F.J., Matzuk, M.M., Tsai, S.Y., and O'Malley, B.W. (2000). Mol. Endocrinol. 14, 1075-1085.

Plant, T.M., Padmanabhan, V., Ramaswamy, S., McConnell, D.S., Winters, S.J., Groome, N., Midgley, A.R., Jr., and McNeilly, A.S. (1997). J. Clin. Endocrinol. Metab. 82, 2617-2621.

Ponce-Castaneda, M.V., Esparza-Lopez, J, Vilchis-Landeros, M.M., Mendoza, V., and Lopez-Casillas, F. (1998). Biochim. Biophys. Acta 1384, 189-196.

Ramaswamy, S., Marshall, G.R., McNeilly, A.S., and Plant, T.M. (2000). Endocrinology 141, 18-27.

Risma, K.A., Clay, C.M., Nett, T.M., Wagner, T., Yun, J., and Nilson, J.H. (1995). Proc. Natl. Acad. Sci. U.S.A. 92, 1322-1326.

Rivier, C., Rivier, J., and Vale, W. (1986). Science 234, 205-208.

Rivier, J., Spiess, J., McClintock, R., Vaughan, J., and Vale, W. (1985). Biochem. Biophys. Res. Commun. 133, 120-127

Roberts, V.J., Barth, S., el-Roeiy, A., and Yen, S.S. (1993). J. Clin. Endocrinol. Metab. 77, 1402-1410.

Robertson, D.M., Foulds, L.M., Leversha, L., Morgan, F.J., Hearn, M.T., Burger, H.G., Wettenhall, R.E., and de Kretser, D.M. (1985). Biochem. Biophys. Res. Commun. 126, 220-226.

Sanchez, M.P., Silos-Santiago, I., Frisen, J., He, B., Lira, S.A., and Barbacid, M. (1996). Nature 382, 70-73.

Schmitt, J., Hotten, G., Jenkins, N.A., Gilbert, D.J., Copeland, N.G., Pohl, J., and Schrewe, H. (1996). Genomics 32, 358-366.

Schuchardt, A., D'Agati, V., Larsson-Blomberg, L., Costantini, F., and Pachnis, V. (1994). Nature 367, 380-383.

Schwall, R.H., Robbins, K., Jardieu, P., Chang, L., Lai, C., and Terrell, T.G. (1993). Hepatology 18, 347-356.

Schwartz, N.B., and Channing, C.P. (1977). Proc. Natl. Acad. Sci. U.S.A. 74, 5721-5724.

Sehested, A., Juul, A.A., Andersson, A.M., Petersen, J.H., Jensen, T.K., Muller, J., and Skakkebaek, N.E. (2000). J. Clin. Endocrinol. Metab. 85, 1634-1640.

Silverman, L.A., Gitelman, S.E., Woodruff, T.K., and Grumbach, M.M. (1994). Pediat. Res. 35, A107.

Stehle, J.H., Foulkes, N.S., Molina, C.A., Simonneaux, V., Pevet, P., and Sassone-Corsi, P. (1993). Nature 365, 314-320.

Stewart, C.J., Jeffers, M.D., and Kennedy, A. (1997). Histopathology 31, 67-74.

Stouffer, R.L., Dahl, K.D., Hess, D.L., Woodruff, T.K., Mather, J.P., and Molskness, T.A. (1994). Biol. Reprod. 50, 888-895. 
Tanimoto, K., Yoshida, E., Mita, S., Nibu, Y., Murakami, K., and Fukamizu, A. (1996). J. Biol. Chem. 271, 32760-32769.

ten Dijke, P., Ichijo, H., Franzen, P., Schulz, P., Saras, J., Toyoshima, H., Heldin, C.H., and Miyazono, K. (1993). Oncogene 8, 2879-2887.

ten Dijke, P., Yamashita, H., Ichijo, H., Franzen, P., Laiho, M., Miyazono, K., and Heldin, C.H. (1994). Science 264, 101-104.

Treanor, J.J., Goodman, L., de Sauvage, F., Stone, D.M., Poulsen, K.T., Beck, C.D., Gray, C., Armanini, M.P., Pollock, R.A., Hefti, F., Phillips, H.S., Goddard, A., Moore, M.W., Buj-Bello, A., Davies, A.M., Asai, N., Takahashi, M., Vandlen, R., Henderson, C.E., and Rosenthal, A. (1996). Nature 382, 80-83.

Trupp, M., Ryden, M., Jornvall, H., Funakoshi, H., Timmusk, T., Arenas, E., and Ibanez, C.F. (1995). J. Cell. Biol. 130, 137-148.

Tsuchida, K., Mathews, L.S., and Vale, W.W. (1993). Proc. Natl. Acad. Sci. U.S.A. 90, 11242-11246.

Tsuchida, K., Vaughan, J.M., Wiater, E., Gaddy-Kurten, D., and Vale, W.W. (1995). Endocrinology 136, 5493-5503.

Turner, I.M., Saunders, P.T., Shimasaki, S., and Hillier, S.G. (1989). Endocrinology 125, 2790-2792.

Tuuri, T., Framaa, M., Van Schaik, R.H., and Ritvos, O. (1996). Mol. Cell. Endocrinol. 121, 1-10.

Vale, W., Rivier, J., Vaughan, J, McClintock, R., Corrigan, A., Woo, W., Karr, D., and Spiess, J. (1986). Nature 321, 776-779.

Vale, W., Rivier, C., Hsueh, A., Campen, C., Meunier, H., Bicsak, T., Vaughan, J., Corrigan, A., Bardin, W., Sawchenko, P., et al. (1988). In "Recent Progress in Hormone Research," vol. 44, pp. 1-34. Academic Press, San Diego, Calif.

van der Geer, P., Hunter, T., and Lindberg, R.A. (1994). Anmu. Rev. Cell. Biol. 10, 251 -337.

Vassalli, A., Matzuk, M.M., Gardner, H.A., Lee, K.F., and Jaenisch, R. (1994). Genes Dev. 8, 414-427.

Wang, X.F., Lin, H.Y., Ng-Eaton, E., Downward, J., Lodish, H.F., and Weinberg, R.A. (1991). Cell 67, 797-805.

Watson, R.H., Roy, W.J., Jr., Davis, M., Hitchcock, A., and Campbell, J.G. (1997). Gynecol. Oncol. 65, 387-390.

Welt, C.K., Lambert-Messerlian, G., Zheng, W., Crowley, W.F., Jr., and Schneyer, A.L. (1997a). $J$. Clin. Endocrinol. Metab. 82, 3720-3727.

Welt, C.K., Martin, K.A., Taylor, A.E., Lambert-Messerlian, G.M., Crowley, W.F., Jr., Smith, J.A., Schoenfeld, D.A., and Hall, J.E. (1997b). J. Clin. Endocrinol. Metab. 82, 2645-2652.

Welt, C.K., McNicholl, D.J., Taylor, A.E., and Hall, J.E. (1999). J. Clin. Endocrinol. Metab. 84, 105-111.

Wiesmann, C., and de Vos, A.M. (2000). Nature Struct. Biol. 7, 440-442.

Woodruff, T.K. (1998). Biochem. Pharmacol. 55, 953-963.

Woodruff, T.K. (1999). Endocrinology 140, 3-5.

Woodruff, T.K., and Mather, J.P. (1995). Annu. Rev. Physiol. 57, 219-244.

Woodruff, T.K., and Mayo, K.E. (1990). Annu. Rev. Physiol. 52, 807-821.

Woodruff, T.K., Meunier, H., Jones, P.B., Hsueh, A.J., and Mayo, K.E. (1987). Mol. Endocrinol. 1, 561-568.

Woodruff, T.K., D'Agostino, J., Schwartz, N.B., and Mayo, K.E. (1988). Science 239, 1296-1299.

Woodruff, T.K., D'Agostino, J., Schwartz, N.B., and Mayo, K.E. (1989). Endocrinology 124, 2193 2199.

Woodruff, T.K., Krummen, L., Chen, S.A., Lyon, R., Hansen, S.E., DeGuzman, G., Covello, R., Mather, J., and Cossum, P. (1993a). Endocrinology 132, 725-734.

Woodruff, T.K., Krummen, L.A., Lyon, R.J., Stocks, D.L., and Mather, J.P. (1993b). Endocrinology 132, 2332-2341.

Woodruff, T.K., Besecke, L.M., Groome, N., Draper, L.B., Schwartz, N.B., and Weiss, J. (1996). Endocrinology 137, 5463-5467. 
Wrana, J.L., Attisano, L., Carcamo, J., Zentella, A., Doody, J., Laiho, M., Wang, X.F., and Massague, J. (1992). Cell 71, 1003-1014.

Wrana, J.L., Attisano, L., Wieser, R., Ventura, F., and Massague, J. (1994). Nature 370, 341-347.

Xu, J., McKeehan, K., Matsuzaki, K., and McKeehan, W.L. (1995). J. Biol. Chem. 270, 6308-6313.

Yamashita, H., ten Dijke, P., Huylebroeck, D., Sampath, T.K., Andries, M., Smith, J.C., Heldin, C.H., and Miyazono, K. (1995). J. Cell. Biol. 130, 217-226.

Yamashita, K., Yamoto, M., Shikone, T., Minami, S., Imai, M., Nishimori, K., and Nakano, R. (1997). Am. J. Obstet. Gynecol. 177, 1450-1457.

Ying, S.Y. (1988). Endocr. Rev, 9, 267-293.

Zheng, W., Sung, C.J., Hanna, I., DePetris, G., Lambert-Messerlian, G., Steinhoff, M., and Lauchlan, S.C. (1997). Intl. J. Gynecol. Pathol. 16, 263-271. 